\title{
Nutritional characteristics in leaves of plants native to tropical peat swamps and heath forests of Central Kalimantan, Indonesia
}

\author{
Sehat Jaya TUAH ${ }^{1,2}$, and Yahya Mika JAMAL ${ }^{2)} \&$ Suwido Hester Limin ${ }^{2}$ \\ ${ }^{1)}$ Graduate School of Agriculture, Hokkaido University, Kita 9, Nishi 9, Kitaku, Sapporo, 060-8589, Japan \\ ${ }^{2)}$ Center for International Cooperation in Management of Tropical Peatland, Palangka Raya University, \\ Palangka Raya 73112, Central Kalimantan, Indonesia
}

\begin{abstract}
Thirteen mineral element concentrations in leaf samples of 478 native plants growing in peat swamps and heath forests of Central Kalimantan were determined. Chemical properties of surface soils in the study sites were also determined. In all sampling sites the mean concentrations of essential macro-elements were less variable than that of micro-elements. The chemical properties of surface soils necessitate that the peat and sandy podzolic soils are nutrient-limited. However, some native plants growing on these soils show a preference to accumulate excessive concentrations of particular micro-elements, such as $\mathrm{Na}, \mathrm{Mn}, \mathrm{Al}$, and $\mathrm{Si}$, in their leaves. The results of this study confirm that the concentrations of elements in plant leaves appear to be indicative of site variation and are the result of environmental adaptation. $\mathrm{Al}, \mathrm{Si}$, and $\mathrm{Na}$ were the principal elements determining the nutritional characteristics of the native plant leaves. However, only $\mathrm{Al}$ has clear inter-element relationships for each plant group. Therefore, the relationships between $\mathrm{Al}-\mathrm{Na}$ and $\mathrm{Al}-\mathrm{Si}$ in leaves reveal important strategies of plant adaptation to the nutrient-poor ecosystems of peat swamps and heath forests. Native plants belonging to the Eurosid I evolutionary group had very high $\mathrm{Al}$ concentrations in their leaves, both in Lahei and Kalampangan peat swamp forests. Combretocarpus rotundatus (Anisophylleaceae family) was predominant in the study sites and, could be regarded as an $\mathrm{Al}$ accumulating species (leaf $\mathrm{Al}$ concentration within the range of $2,000-10,000 \mathrm{mg} \mathrm{kg}^{-1}$ ). $\mathrm{Al}$-accumulating species likely restrict the accumulation of other mineral elements in their leaves, whereas non $\mathrm{Al}$-accumulating species tend to accumulate other mineral elements in their leaves. Although the mechanism for this eco-physiological adaptation remains unclear, it is suspected that $\mathrm{Al}$-accumulating species (c.f. C. rotundatus) have developed efficient strategies enabling them to utilize low amounts of essential elements in order to be able to grow in a nutrient-limited environment. Information gathered about Al-accumulation by certain wild plants will be useful in selecting appropriate species to rehabilitate damaged peat swamp and heath forests.
\end{abstract}

Key words: peat swamp forest, heath forest, mineral element concentrations, native plants, Combretocarpus rotundatus, $\mathrm{Al}$-accumulating species, phylogeny

\section{INTRODUCTION}

Indonesia contains the largest area of tropical peatland, estimated at 20 million hectares (Radjagukguk 1997) of which 2.5 million hectares are located in Central Kalimantan. Peatlands are wetland ecosystems that are characterized by the accumulation of organic matter, which is produced and deposited at a rate greater than its decomposition, leading to the formation of peat. Within tropical peatlands, inland and transitional peat have been recognized as being particularly nutrient-poor due to their very high acidity and organic matter content, especially lignin (Polak 1975). A lignin content of about 50 - 60\% was observed in the peat soil from Central Kalimantan (Artiningsih 1999). High 
aluminum (Al) concentration in soil solutions is also known to be the main factor restricting growth of plants on acidic soils (Rao et al. 1993; Watanabe \& Osaki 2002). However, numerous native plants are well adapted to such environments and do not exhibit symptoms of nutrient deficiency or toxicity and, in fact, grow vigorously. This indicates that these plants have adaptation mechanisms to maintain their growth and development in the harsh environment of the lowland peatland ecosystem. Osaki et al. (1998) reported that some native plants such as Melastoma malabatricum and Melaleuca cajuputi, that grow in various adverse soils in Peninsular Thailand, have outstanding characteristics in relation to $\mathrm{Al}$ and $\mathrm{Na}$ accumulation in leaves, even though the $\mathrm{Al}$ and $\mathrm{Na}$ concentrations in the soil are very low. On the other hand, these native plants have low concentrations of $\mathrm{Na}$ and $\mathrm{Al}$ in soils with high $\mathrm{Na}$ and $\mathrm{Al}$ concentrations. It is assumed that the $\mathrm{Al}$ and $\mathrm{Na}$ accumulator plants have a tendency to exclude other mineral elements from their leaves, suggesting that these accumulator plants have developed efficient mechanisms to utilize small amounts of essential nutrients for their growth (Osaki et al. 2002).

Native plants constitute important components of ecosystems, as they recycle elements and provide transport pathways from the non-living to the living environment (Hamilton 1995). However, elements within plants are not cycled independently. Because they are involved in the basic structure and function of cells, these elements have similar biochemical pathways (Garten 1976). In an analysis of a wide array of plant traits, Grime et al. (1997) suggested that mineral nutrients be considered as the fundamental currency of vegetation processes, from the individual level to the ecosystem level. Thus, assuming that native plants can absorb and accumulate nutrients selectively and maintain a balance of intercellular concentrations to optimize their growth (Garten 1976), it is argued that the specific elemental concentrations of these plants reflect the nutrient concentration ratios in their substrate (Markert 1996).

Studies of elemental traits in native plants, particularly trees, are difficult because of plant size and longevity (Attiwill 1980) and differences in the storage of nutrients in particular plant organs, chemical fractions and cellular compartments (Chapin 1988). Most studies have, therefore, been based on changes in the concentrations of nutrients in various tissues, particularly leaves (Masunaga et al. 1997; Osaki et al. 1998; Pampasit et al. 2000). Because of strong interrelationships between foliar N, P, K, Ca, and $\mathrm{Mg}$ concentrations in some species (Garten 1976; Grime et al. 1997), Aerts \& Chapin (2000) concluded that leaf nutrient concentrations are important determinants of plant function and development. Comparative studies of leaf nutrient concentrations in 54 species of non-vascular and vascular plants, as well as aquatic macrophytes (Garten 1976), 83 species of herbaceous flora (Thompson et al. 1997) and native plants of humid tropical lowlands (Osaki et al. 2000), have pointed out important relationships between mineral elements. These relationships derive mostly from both specie and site specific characteristics. This study, therefore, aimed to clarify a general characteristic of mineral element concentration in leaves and also describe the relationship between the concentrations of mineral elements across a variety of native plant species and site conditions in tropical peat swamps and heath forests in Central Kalimantan, Indonesia. 


\section{MATERIALS AND METHODS}

\section{Study Sites}

Study sites were established at three different locations: Kalampangan, Setia Alam, and Lahei (Fig. 1). The study site in the Kalampangan area comprised of a primary or natural peat swamp forest and a fire-damaged area of inland peat. A primary (natural) peat swamp forest site is defined as a relatively undisturbed area of peat swamp forest, whereas fire-damaged areas are defined as those areas affected by the massive wildfires of 1996-1997. The study site in Setia Alam area included a relatively undisturbed peat swamp forest, as well as a logged forest, whereas the Lahei site included two adjacent, contrasting, forest types of peat swamp and kerangas (heath) forest. In addition, the native plants in these three different sites grow in deep, intermediate, and shallow peat depths, respectively.

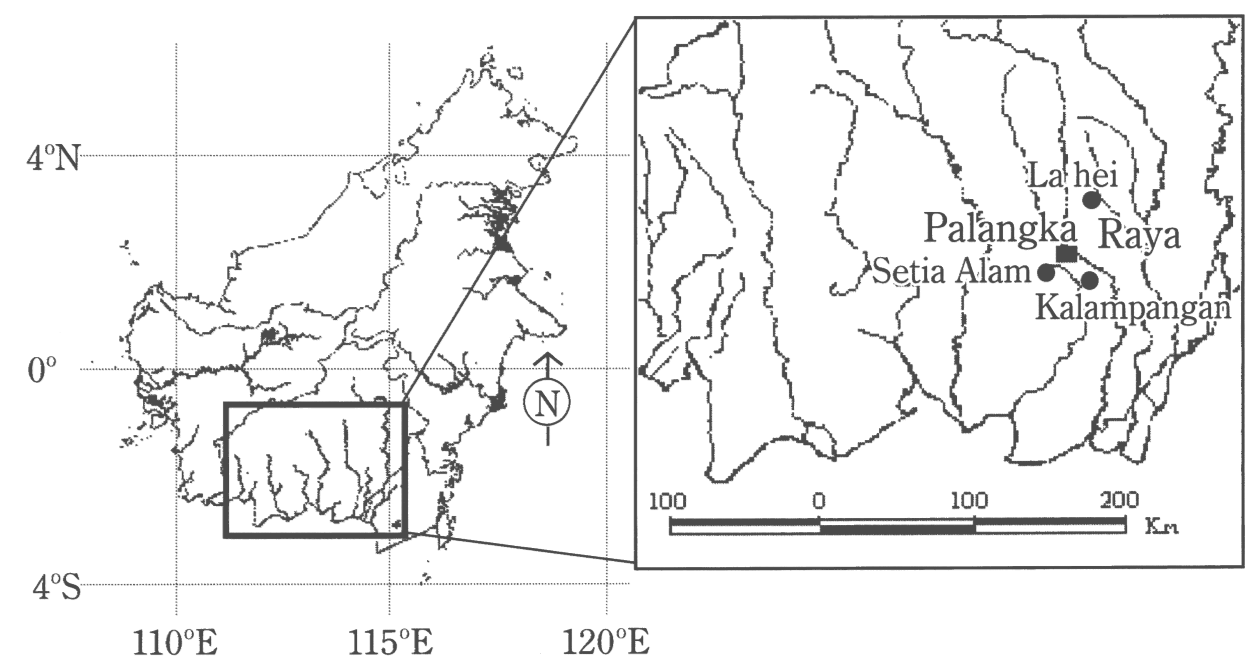

Fig. 1. Location of the study sites and field samplings in the peat swamps and heath forests in Central Kalimantan, Indonesia.

Species composition within the Kalampangan and Setia Alam sites, as determined by field survey, were relatively similar. The dominant tree species included: Tetrameristra glabra, Calophyllum sp., Shorea sp., Combretocarpus rotundatus, Palaquium sp., Buchanania sessifolia, Syzygium sp., Dactylocladus stenostachys, Dyera costulata, Ilex cymosa, Tristaniopsis obovata, and Dyospyros sp. The species composition at the Lahei site according to Suzuki et al. (1998) was dominated by Buchanania sessifolia, Baccaurea macrocarpa, Gluta rugulosa, Shorea balangeran, Dyospyros sp., Semecarpus sp., and Ganua motleyana in the peat swamp forest and Calophyllum sp., Palaquium sp., Canarium sp., and some important species of the dipterocarp family in the heath forest.

\section{Sample Collection and Preparation}

Mature and fully expanded leaves (including shoots) of some dominant tree species $\geq 10 \mathrm{~cm}$ in diameter 
at breast height (DBH) were sampled. The upper leaves of several fern species were also collected, particularly within the fire-damaged area of the Kalampangan site.

The collected leaves were washed with deionized water, dried in an air-forced oven at $80^{\circ} \mathrm{C}$ for 72 hours, and then ground in a tungsten carbide vibrating mixer mill C.M.T. TI-100 (C.M.T. Co. Ltd., Japan). The plant species that were sampled and analyzed in this study are listed in Appendix 1.

Soil samples were also collected at each sampling site using a peat soil auger from Eijkelkamp Agrisearch Equipment (about $50 \mathrm{~cm}$ in depth). Five points were sampled at each study site, and the samples collected were subsequently mixed and air-dried at room temperature. The dried soils were ground and sieved through a $2 \mathrm{~mm}$ mesh.

\section{Analytical Methods}

Prior to determining the total elemental concentration of leaves, about $100 \mathrm{mg}$ of finely ground samples were digested in a mixed solution of $\mathrm{H}_{2} \mathrm{SO}_{4}-\mathrm{H}_{2} \mathrm{O}_{2}$, according to the method used by Mizuno and Minami (1980). Total $\mathrm{N}$ concentration was determined by the semi-micro Kjeldahl method, whereas total concentrations of $\mathrm{P}, \mathrm{K}, \mathrm{Ca}, \mathrm{Mg}, \mathrm{Na}, \mathrm{Mn}, \mathrm{Fe}, \mathrm{Zn}, \mathrm{Cu}, \mathrm{Mo}, \mathrm{Al}$, and $\mathrm{Si}$ were measured by Inductively Coupled Plasma Atomic Spectrometry (ICPS-7000, SHIMADZU, Japan). The total Si concentration reported in this paper does not include acid insoluble $\mathrm{Si}$, because the digestion method used can only measure acid soluble Si. Fresh soil $\mathrm{pH}(1: 2.5=$ soil:deionized water; $\mathrm{v} / \mathrm{v})$ was measured in the field using a portable $\mathrm{pH}$ combination electrode (TOA Electronics Ltd., Japan). Exchangeable $\mathrm{Ca}, \mathrm{Mg}$, and $\mathrm{K}$ concentrations in the soils were determined by atomic absorption spectrophotometry (AA-6200, SHIMADZU, Japan) for $\mathrm{Ca}$ and $\mathrm{Mg}$ and flame photometry for $\mathrm{K}$ after extraction with $1 \mathrm{~N} \mathrm{KCl}$ (soil: $\mathrm{KCl}$ $=1: 20$ ). Atomic absorption spectrophotometry was also used to determine available $\mathrm{Cu}, \mathrm{Zn}$ and $\mathrm{Mn}$ after extraction with $0.05 \mathrm{~N} \mathrm{HCl}$. The amount of available $\mathrm{P}$ in the soils was determined by the Bray II method, whereas N and C content were measured using a C-N Analyzer (SUMIGRAPH NC-1000, Japan).

\section{Data and Statistical Analysis}

The general tendency of mineral elements to accumulate in the plants studied was described according to the phylogenetic classification of each plant, as inferred from analysis of $r b c \mathrm{~L}$, atp B, and $18 \mathrm{~S}$ rDNA sequences (Chase et al. 1993; Angiosperm Phylogeny Group 1998; Soltis et al. 1999). The INKEY online program of Watson \& Dallwitz (http://biodiversity.uno.edu/delta/, version $14^{\text {th }}$ December 2000) was also used for classification.

Statistical analysis was conducted using the SPSS program (SPSS Science, Chicago, USA).

\section{RESULTS}

\section{Chemical Properties of the Soils}

Surface soils in all the study sites were strongly acidic $(\mathrm{KCl} \mathrm{pH}<3)$ and the $\mathrm{KCl} \mathrm{pH}$ was consistently lower than the $\mathrm{H}_{2} \mathrm{O} \mathrm{pH}$. The $\mathrm{pH}\left(\mathrm{H}_{2} \mathrm{O}\right)$ of peat soil ranged from $3.3-4.0$, and was about 4.1 in sandy podzolic soil. Both $\mathrm{H}_{2} \mathrm{O} \mathrm{pH}$ and $\mathrm{KCl} \mathrm{pH}$ were slightly higher in sandy podzolic soil than in peat soil. Highly acidic soil may have a low availability of essential nutrients. The chemical properties of surface soils in the study sites showed that there was less $\mathrm{N}$ and $\mathrm{C}$, as well as available $\mathrm{P}$, in sandy podzolic soil 
than in the peat soil. Exchangeable $\mathrm{Ca}$ and $\mathrm{Mg}$ were found in moderate amounts in sandy podzolic soil, while exchangeable $\mathrm{K}$ was very low. $\mathrm{Cu}$ and $\mathrm{Mn}$ were found in relatively higher amounts in sandy podzolic soil than in the peat soil, while $\mathrm{Zn}$ was detected in moderate concentration. Compared to the other peat soil sampling sites, Kalampangan soil, having a deep peat layer (K2), has relatively high amounts of available $\mathrm{P}, \mathrm{C}$, as well as exchangeable $\mathrm{Ca}$ and $\mathrm{Mg}$. In general, the chemical properties of surface soils in the study sites, as summarized in Table 1, indicate both peat and sandy podzolic soils are nutrient limited substrates, and most nutrients are likely stored in above-ground biomass. Therefore, it is evident that the native plants growing in these soils compete and have particular strategies for the acquisition of mineral nutrients for growth.

Table 1. Chemical properties of soil from surface to $50 \mathrm{~cm}$ depth in the study sites of peat swamps and heath forests in Central Kalimantan, Indonesia.

\begin{tabular}{|c|c|c|c|c|c|c|c|c|c|c|c|c|c|}
\hline \multirow{3}{*}{ Sampling Site } & \multirow{3}{*}{ Code } & \multirow{3}{*}{ Soil type } & \multirow{3}{*}{$\mathrm{pH}(\mathrm{KCl})$} & \multirow{3}{*}{$\mathrm{pH}\left(\mathrm{H}_{2} \mathrm{O}\right)$} & \multirow{3}{*}{$\begin{array}{c}\text { Bray II } \\
\mathrm{P}_{2} \mathrm{O}_{5} \\
\left(\mathrm{mg} \mathrm{kg}^{-1}\right)\end{array}$} & \multirow{3}{*}{$\begin{array}{c}\mathrm{N} \\
(\%)\end{array}$} & \multirow{3}{*}{$\begin{array}{c}\mathrm{C} \\
(\%)\end{array}$} & \multicolumn{3}{|c|}{ Exchangable cations } & \multirow{3}{*}{$\mathrm{Cu}$} & \multirow{3}{*}{$\frac{\mathrm{Zn}}{\mathrm{mg} \mathrm{kg}^{-1}}$} & \multirow{3}{*}{$\mathrm{Mn}$} \\
\hline & & & & & & & & $\mathrm{Ca}$ & $\mathrm{Mg}$ & $\mathrm{K}$ & & & \\
\hline & & & & & & & & \multicolumn{3}{|c|}{$\left(\mathrm{cmol}_{\mathrm{c}} \mathrm{kg}^{-1}\right)$} & & & \\
\hline Lahei & L1 & Peat (intermediate) & 2.4 & 3.4 & 98 & 1.4 & 37.2 & 0.13 & 0.88 & 0.43 & 0.12 & 5.03 & 0.60 \\
\hline Lahei & $\mathrm{L} 2$ & Sandy podzolic & 2.7 & 4.1 & 54 & 0.5 & 18.9 & 0.16 & 0.55 & 0.34 & 0.40 & 3.37 & 1.85 \\
\hline Kalampangan & K1 & Peat (deep) & 2.2 & 3.3 & 96 & 1.3 & 38.1 & 0.14 & 0.79 & 0.60 & 0.16 & 6.89 & 1.70 \\
\hline Kalampangan & $\mathrm{K} 2$ & Peat (deep) & 2.2 & 3.7 & 167 & 1.1 & 39.7 & 0.41 & 1.58 & 0.64 & 0.01 & 4.15 & 0.40 \\
\hline Kalampangan & $\mathrm{K} 3$ & Peat (shallow) & 2.4 & 4.0 & 44 & 1.4 & 38.8 & 0.04 & 0.44 & 0.45 & 0.14 & 1.91 & 0.30 \\
\hline Kalampangan & $\mathrm{K} 4$ & Peat (shallow) & 2.2 & 3.7 & 77 & 1.3 & 38.2 & 0.15 & 0.77 & 1.23 & 0.05 & 3.13 & 0.10 \\
\hline Setia Alam & S1 & Peat (shallow) & 2.3 & 3.7 & 69 & 1.4 & 36.8 & 0.14 & 0.78 & 0.41 & 0.13 & 5.07 & 0.40 \\
\hline Setia Alam & S2 & Peat (deep) & 2.2 & 3.6 & 66 & 0.9 & 39.7 & 0.17 & 1.12 & 0.51 & 0.13 & 5.55 & 0.50 \\
\hline
\end{tabular}

\section{Foliar Element Concentrations of Native Plants Growing at Various Sites}

The total concentrations of various macro- and micro-elements in the leaves of 478 native plant samples from the three study sites are compiled in Appendix 1. Elemental concentrations in the leaves varied remarkably among plant species growing in tropical peat swamps and heath forests in Central Kalimantan, Indonesia (Table 2). The concentration of some elements was high at certain sampling sites. Compared with the micro-elements, less variation occurred among the macro-elements, indicating that the maintenance of a cellular balance of these nutrients is not site specific. Analytical results (Table 2) show that macro-element concentrations $\left(\mathrm{g} \mathrm{kg}^{-1}\right)$ varied within the range of 4.1-35.0 for $\mathrm{N}, 0.1-2.5$ for $\mathrm{P}, 1.8-25.6$ for $\mathrm{K}, 0.7-28.7$ for $\mathrm{Ca}$, and $0.4-21.3$ for $\mathrm{Mg}$. The concentrations of various micro-elements ( $\mathrm{mg} \mathrm{kg}^{-1}$ ) varied within the range of 1.4-3753 for $\mathrm{Na}, 4.5-553$ for $\mathrm{Fe}, 2.3-2111$ for $\mathrm{Mn}$, 0.1-85 for $\mathrm{Zn}, 0.04-14$ for $\mathrm{Cu}, 0.9-18$ for $\mathrm{Mo}, 0.9-10019$ for $\mathrm{Al}$, and 0.4-3616 for Si. In spite of the heterogeneity of the study sites, $\mathrm{P}$ concentration remained consistently very low compared to the other macro-elements studied ( $\mathrm{N}, \mathrm{K}, \mathrm{Ca}$, and $\mathrm{Mg}$ ).

The element concentrations in the leaves of native plants of the study sites were compared with nutrient concentrations in leaves of native plants (mostly trees) from the tropical rain forest in Pinang-pinang, West Sumatra, Indonesia (Masunaga et al. 1997), and also native plants from the tropical dry evergreen forest in Sakaerat, Thailand (Sirirattanakon 1999) (Table 2). It is shown that, except for $\mathrm{Mg}$, the macro-elements measured $(\mathrm{N}, \mathrm{P}, \mathrm{K}$, and $\mathrm{Ca}$ ) in the plant leaves of the study sites were lower than that of the tropical plant leaves in West Sumatra and Sakaerat. However, the concentrations of micro-elements varied greatly by site and specie. $\mathrm{Al}$ and $\mathrm{Si}$, in particular, had a clear preference to accumulate in a considerably high concentration in some native plants' leaves as indicated in all three 
different locations (Table 2). Therefore, certain micro-elements, especially $\mathrm{Al}$ and $\mathrm{Si}$, are likely to be the key elements of native plant growth in nutrient-limited environments. In this study, element concentrations, especially that of micro-elements, in leaves of native plants varied greatly. Several native plants showed a preference to accumulate particular elements such as $\mathrm{Na}, \mathrm{Mn}, \mathrm{Al}$, and $\mathrm{Si}$ in great concentrations, above the average concentration required for adequate plant growth (Appendix 1). In addition, concentrations of these micro-elements in plant leaves had a high coefficient of variation (CV), indicating that excessive absorption and/or accumulation is a specific characteristic of certain plants. In general, the average concentration of macro-elements in the leaves of the plants studied was greatest for $\mathrm{N}$ followed by $\mathrm{K}, \mathrm{Ca}, \mathrm{Mg}, \mathrm{P}$; for micro-elements the greatest concentration was that of $\mathrm{Na}$, followed by $\mathrm{Si}, \mathrm{Al}, \mathrm{Mn}, \mathrm{Fe}, \mathrm{Mo}, \mathrm{Zn}, \mathrm{Cu}$ (Table 2).

Table 2. Magnitude of elemental concentrations in leaves of native plants from several sites in Central Kalimantan in comparison to the concentration of mineral elements in leaves of tropical native plants from two different locations: Pinang-pinang, West Sumatra (Indonesia) and Sakaerat, Changwat Nakhon Ratchasima (Thailand). In parenthesis, $n=$ the total number of plant samples from all sampling sites.

\begin{tabular}{|c|c|c|c|c|c|c|c|c|c|c|c|c|c|}
\hline \multirow[t]{2}{*}{ Parameters } & $\mathrm{N}$ & $\mathrm{P}$ & $\mathrm{K}$ & $\mathrm{Ca}$ & $\mathrm{Mg}$ & $\mathrm{Na}$ & $\mathrm{Fe}$ & $\mathrm{Mn}$ & $\mathrm{Zn}$ & $\mathrm{Cu}$ & Mo & $\mathrm{Al}$ & $\mathrm{Si}$ \\
\hline & \multicolumn{5}{|c|}{$\left(\mathrm{g} \mathrm{kg}^{-1}\right)$} & \multicolumn{8}{|c|}{$\left(\mathrm{mg} \mathrm{kg}^{-1}\right)$} \\
\hline & \multicolumn{13}{|c|}{ Native plants in Central Kalimantan, Indonesia ${ }^{1)}$} \\
\hline Mean \pm SE $(n=478)$ & $12.6 \pm 0.19$ & $0.5 \pm 0.01$ & $8.0 \pm 0.18$ & $6.5 \pm 0.18$ & $2.8 \pm 0.09$ & $506 \pm 21.5$ & $43 \pm 1.7$ & $190 \pm 12.4$ & $8.4 \pm 0.4$ & $3.3 \pm 0.1$ & $8.6 \pm 0.2$ & $269 \pm 48.1$ & $381 \pm 28.7$ \\
\hline Min. & 4.1 & 0.1 & 1.8 & 0.7 & 0.4 & 1.4 & 4.5 & 2.3 & 0.1 & 0.04 & 0.9 & 0.9 & 0.4 \\
\hline Max. & 35.0 & 2.5 & 25.6 & 28.7 & 21.3 & 3753 & 553 & 2111 & 85 & 14 & 18 & 10019 & 3616 \\
\hline \multirow[t]{2}{*}{$\mathrm{CV}(\%)$} & 33 & 65 & 49 & 60 & 69 & 93 & 85 & 143 & 115 & 75 & 42 & 390 & 165 \\
\hline & \multicolumn{13}{|c|}{ Native plants in West Sumatra, Indonesia ${ }^{2)}$} \\
\hline Mean \pm SE $(n=608)$ & $18.1 \pm 0.19$ & $1.0 \pm 0.02$ & $9.4 \pm 0.21$ & $16.9 \pm 0.42$ & $2.6 \pm 0.06$ & $147 \pm 2.3$ & $156 \pm 3.3$ & $532 \pm 21.7$ & $19 \pm 1.1$ & $10 \pm 0.2$ & nd & $2043 \pm 198$ & $6938 \pm 361$ \\
\hline Min. & 8.6 & 0.4 & 1.0 & 0.8 & 0.2 & 131 & 38 & 4.8 & 0.4 & 0.8 & nd & 1.0 & 248 \\
\hline Max. & 46.6 & 4.3 & 34.4 & 81.7 & 10.5 & 861 & 851 & 3574 & 309 & 64 & nd & 36924 & 89984 \\
\hline \multirow[t]{2}{*}{$\mathrm{CV}(\%)$} & 26 & 42 & 54 & 61 & 55 & 39 & 52 & 100 & 137 & 54 & nd & 239 & 128 \\
\hline & \multicolumn{13}{|c|}{ Native plants in Sakaerat, Thailand ${ }^{3)}$} \\
\hline MeantSE $(n=198)$ & $15.9 \pm 0.41$ & $1.0 \pm 0.051$ & $11.0 \pm 0.54$ & $9.8 \pm 0.29$ & $2.6 \pm 0.12$ & $43 \pm 3.7$ & $121 \pm 10.9$ & $524 \pm 36.6$ & $26 \pm 2.4$ & $9 \pm 0.3$ & nd & $2881 \pm 313$ & nd \\
\hline Min. & 6.9 & 0.1 & 0.6 & 0.7 & 0.3 & trace & trace & 12.8 & 2.9 & 0.4 & nd & trace & nd \\
\hline Max. & 31.3 & 3.7 & 34.4 & 25.3 & 7.2 & 266 & 1149 & 2376 & 286 & 27 & nd & 16568 & nd \\
\hline $\mathrm{CV}(\%)$ & 36 & 68 & 70 & 42 & 63 & 122 & 127 & 98 & 126 & 53 & nd & 153 & nd \\
\hline
\end{tabular}

1) Average of all native plant samples collected in the tropical peat swamps and heath forests in Central Kalimantan, Indonesia(this study).

2) Average of all native plant samples collected in the tropical rain forest in Pinang-pinang, West Sumatra, Indonesia(Masunaga $e t$ al. 1997).

3) Average of all native plant samples collected in the tropical dry evergreen forest in Sakaerat, Thailand (Sirirattanakorn 1999). nd = no data.

Notwithstanding the variability between native plant species, mean concentrations of mineral elements were statistically compared between sampling sites (Table 3). It is shown that the concentrations of various elements measured in the native plants' leaves differed significantly between the study sites. However, $\mathrm{Mg}$ and $\mathrm{Al}$ concentrations in the native plants' leaves did not differ between the sites, while leaf $\mathrm{P}$ concentration was significantly lower in the native plants of both Kalampangan $(\mathrm{K} 1,2,3 \& 4)$ and Setia Alam (S1\&2) than that of the native plants in the Lahei peat swamp and heath forests ( $\mathrm{L} 1$ and L2). Relatively high concentrations of $\mathrm{Na}, \mathrm{Fe}, \mathrm{Zn}, \mathrm{Al}$, and $\mathrm{Si}$ in leaves of the native plants in the peat swamp forest in Lahei (L1) indicate an accumulative behavior of some native plant species at this site. In addition, concentrations of some elements were significantly low in the plant 
leaves, because in most cases the tropical acidic soils are poor in nutrients (Table 1). Despite this fact, undisturbed natural forests seldom reveal symptoms of mineral deficiencies which are typical indicators of degradation. It seems that nutrient balances in undisturbed systems are in a "steady state", and losses, if they occur, are more or less “neutralized" by input rate (Proctor 1987).

Table 3. Concentration of mineral elements (mean $\pm \mathrm{SE}$ ) in mature leaves of native plants growing on various locations in Central Kalimantan. In parentheses, $n=$ number of plant samples. Different letters in the same row indicate a statistically significant difference (LSD-test) among sampling sites at $p<0.05$.

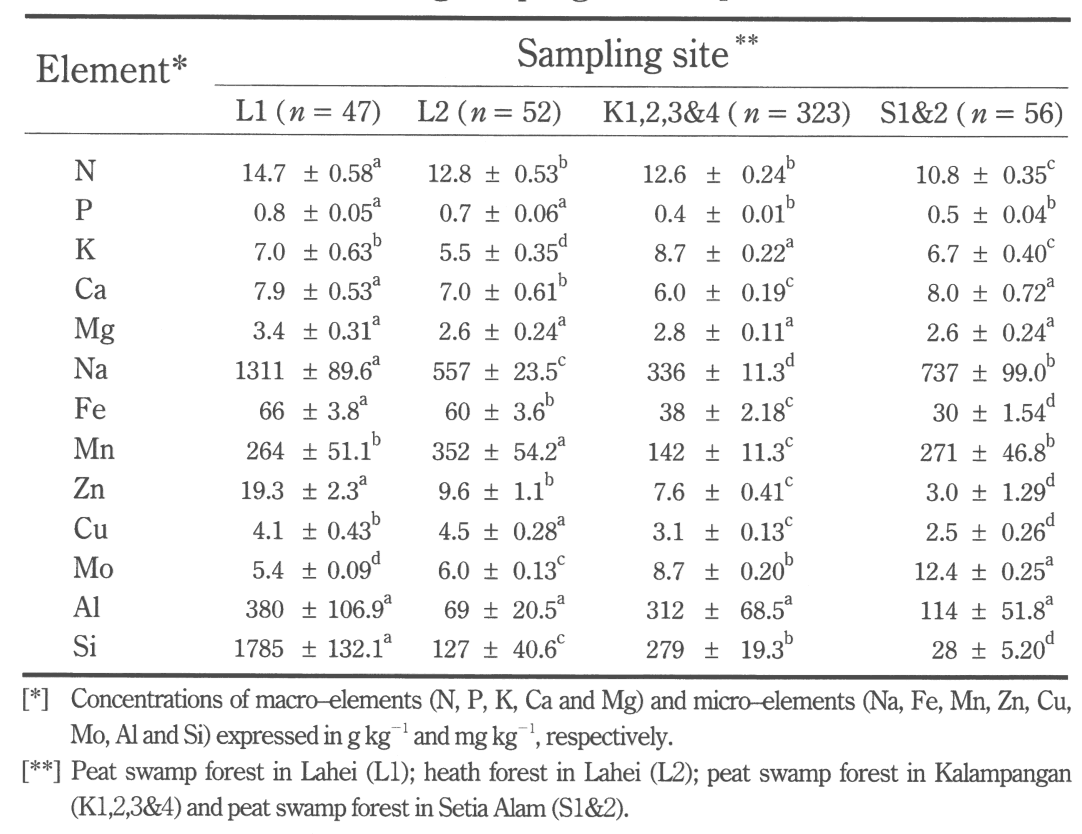

In order to clarify the underlying factors associated with elemental characteristics of the native plants, a Principle Component Analysis was performed to derive the grouping pattern of the native plants studied. The three principal components: Al, Si, and Na (Fig. 2), accounted for $62 \%$ (Component1), 25\% (Component-2) and 8\% (Component-3) of the total variance, respectively (Component Matrix is not shown). Based on these three principal components, all the native plants studied were categorized into three major groups with the Cluster Analysis extraction method. These grouping patterns were predominantly determined by the $\mathrm{Al}$ concentration in the native plants' leaves. Therefore, the three major groups mentioned above were separated into groups of native plant species with relatively low, moderate, and notably high Al-concentrations. Figs. 3, 4 and 5 demonstrate a typical relationship between $\mathrm{Al}, \mathrm{Si}$ and $\mathrm{Na}$, as well as between these three elements and the other elements. However, only $\mathrm{Al}$ clearly shows the inter-element relationships for each plant group (Fig. 3). Thus, Al-accumulating species, the third group, are likely restricting the accumulation of other mineral elements in their leaves, whereas non $\mathrm{Al}$-accumulating species, the first and second groups, tend to accumulate other mineral elements in their leaves. Although the mechanism for their eco-physiological adaptation remains unclear, it is suspected that $\mathrm{Al}$ accumulating species (c.f. C. rotundatus) have developed efficient strategies to utilize lower amounts of essential elements, enabling them to thrive in 
the strongly acidic soil of the peat swamps and heath forests.

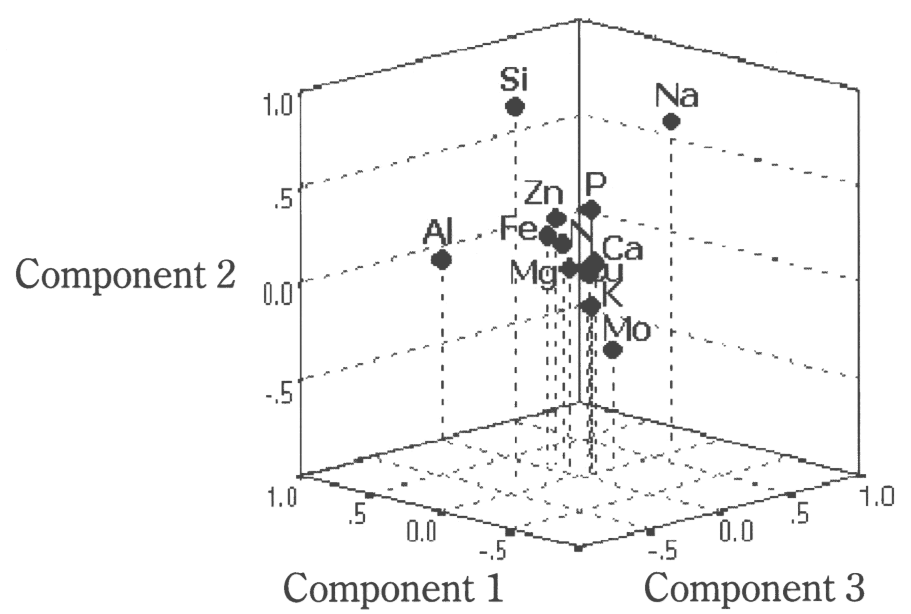

Fig. 2. Plot of mineral element covariance extracted according to a Principal Component Analysis. Component 1,2 and 3 associated with the concentrations of $\mathrm{Al}, \mathrm{Si}$ and $\mathrm{Na}$ which accounted for $62 \%, 25 \%$ and $8 \%$ of the total variance, respectively.

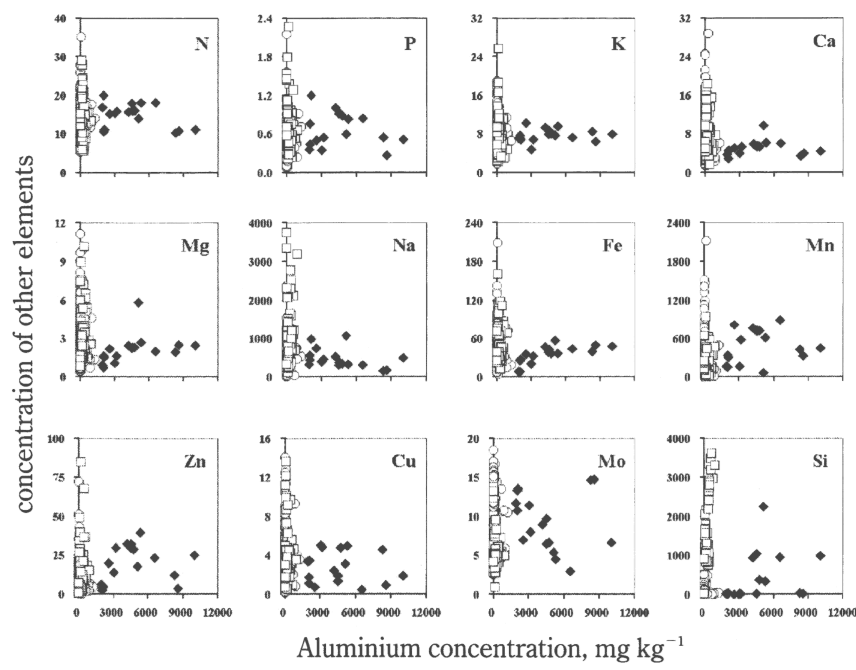

Fig. 3. Relationships between the concentrations of $\mathrm{Al}\left(\mathrm{mg} \mathrm{kg}^{-1}\right)$ and other mineral elements in leaves of native plant species in Central Kalimantan, Indonesia. Concentrations of macro elements (N, P, K, Ca and Mg) and micro elements ( $\mathrm{Na}, \mathrm{Fe}, \mathrm{Mn}, \mathrm{Zn}, \mathrm{Cu}$, Mo and Si) were expressed in $\mathrm{g} \mathrm{kg}^{-1}$ and $\mathrm{mg} \mathrm{kg}^{-1}$, respectively. $(\bigcirc$ : group of native plant species with relatively low Al-concentration; $\square$ : group of native plant species with moderate Al-concentration; and $\diamond$ : group of native plant species with notably high $\mathrm{Al}-$ concentration). 


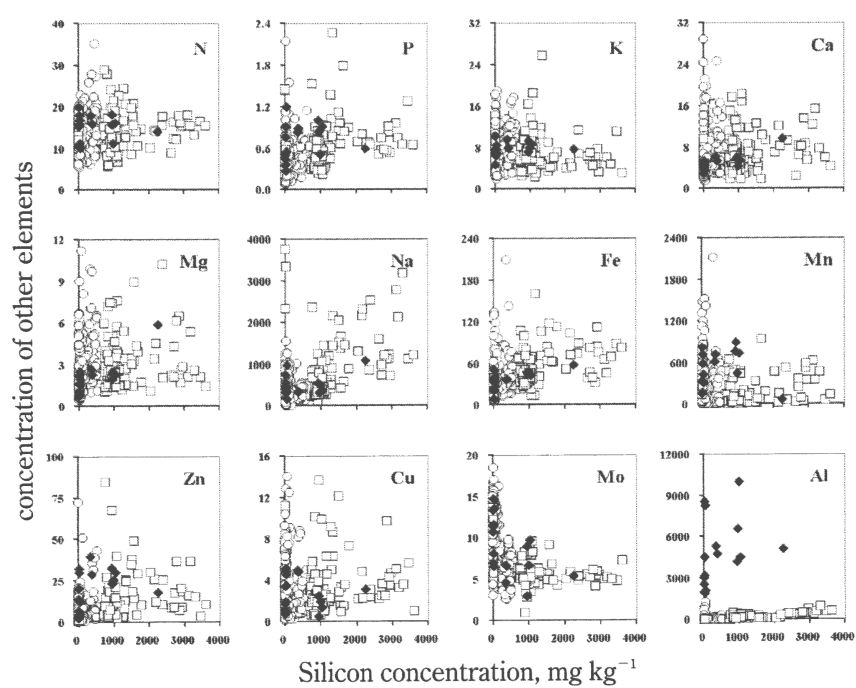

Fig. 4. Relationships between the concentrations of $\mathrm{Si}\left(\mathrm{mg} \mathrm{kg}^{-1}\right)$ and other mineral elements in leaves of native plant species in Central Kalimantan. Concentrations of macro elements (N, P, K, Ca and $\mathrm{Mg}$ ) and micro elements ( $\mathrm{Na}, \mathrm{Fe}, \mathrm{Mn}, \mathrm{Zn}, \mathrm{Cu}, \mathrm{Mo}$ and $\mathrm{Al}$ ) were expressed in $\mathrm{g} \mathrm{kg}^{-1}$ and $\mathrm{mg} \mathrm{kg}^{-1}$, respectively. $(\bigcirc$ : group of native plant species with relatively low Al-concentration; $\square$ : group of native plant species with moderate Al-concentration; and group of native plant species with notably high Al-concentration).
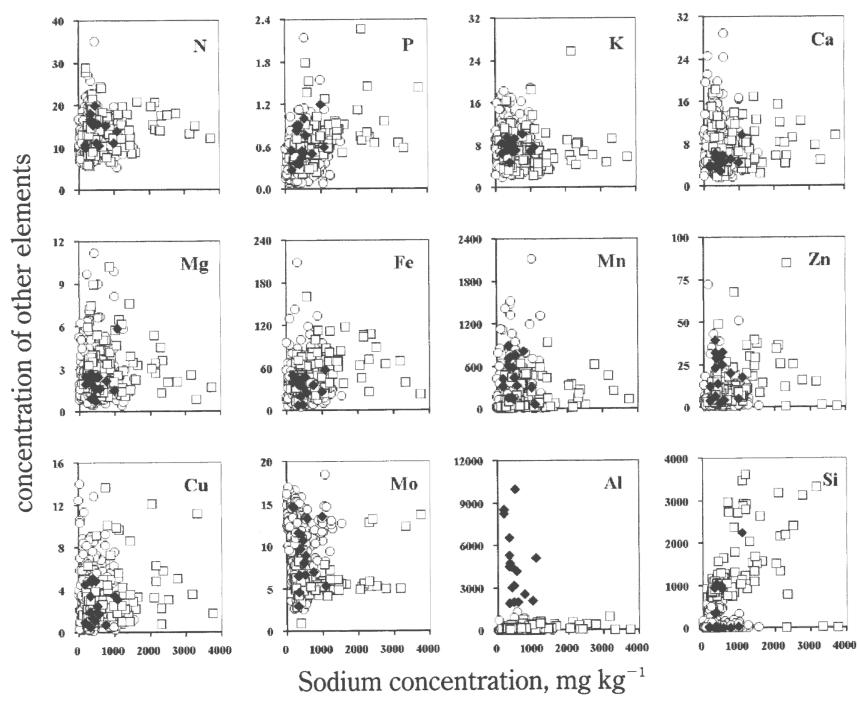

Fig. 5. Relationships between the concentrations of $\mathrm{Na}\left(\mathrm{mg} \mathrm{kg}^{-1}\right)$ and other mineral elements in leaves of native plant species in Central Kalimantan. Concentrations of macro elements (N, P, K, Ca and Mg) and micro elements (Fe, Mn, $\mathrm{Zn}, \mathrm{Cu}, \mathrm{Mo}, \mathrm{Al}$ and $\mathrm{Si}$ ) were expressed in $\mathrm{g} \mathrm{kg}^{-1}$ and $\mathrm{mg} \mathrm{kg}^{-1}$, respectively. ( $\bigcirc$ : group of native plant species with relatively low Al-concentration; $\square$ : group of native plant species with moderate Al-concentration; and $\diamond$ : group of native plant species with notably high Al-concentration). 


\section{Accumulation of Elements in Plant Leaves with Different Phylogeny}

The accumulation of an element in plant tissue may be an environmental adaptation. The accumulative behavior of native plants may therefore be assumed to be ecologically and genetically related. In Figs. 6 and 7 the patterns of element accumulation in the leaves of the native plants were shown for every element studied within the sampling sites. A comparison was made among native plants of different phylogenetic groups, representing plants that evolved a long time ago and more recently evolved plants. Most of the plants studied in all the sampling sites are members of the Ericales, Eurosid II, and Eurosid I phylogenetic groups of recently evolved plants (Appendix 1).
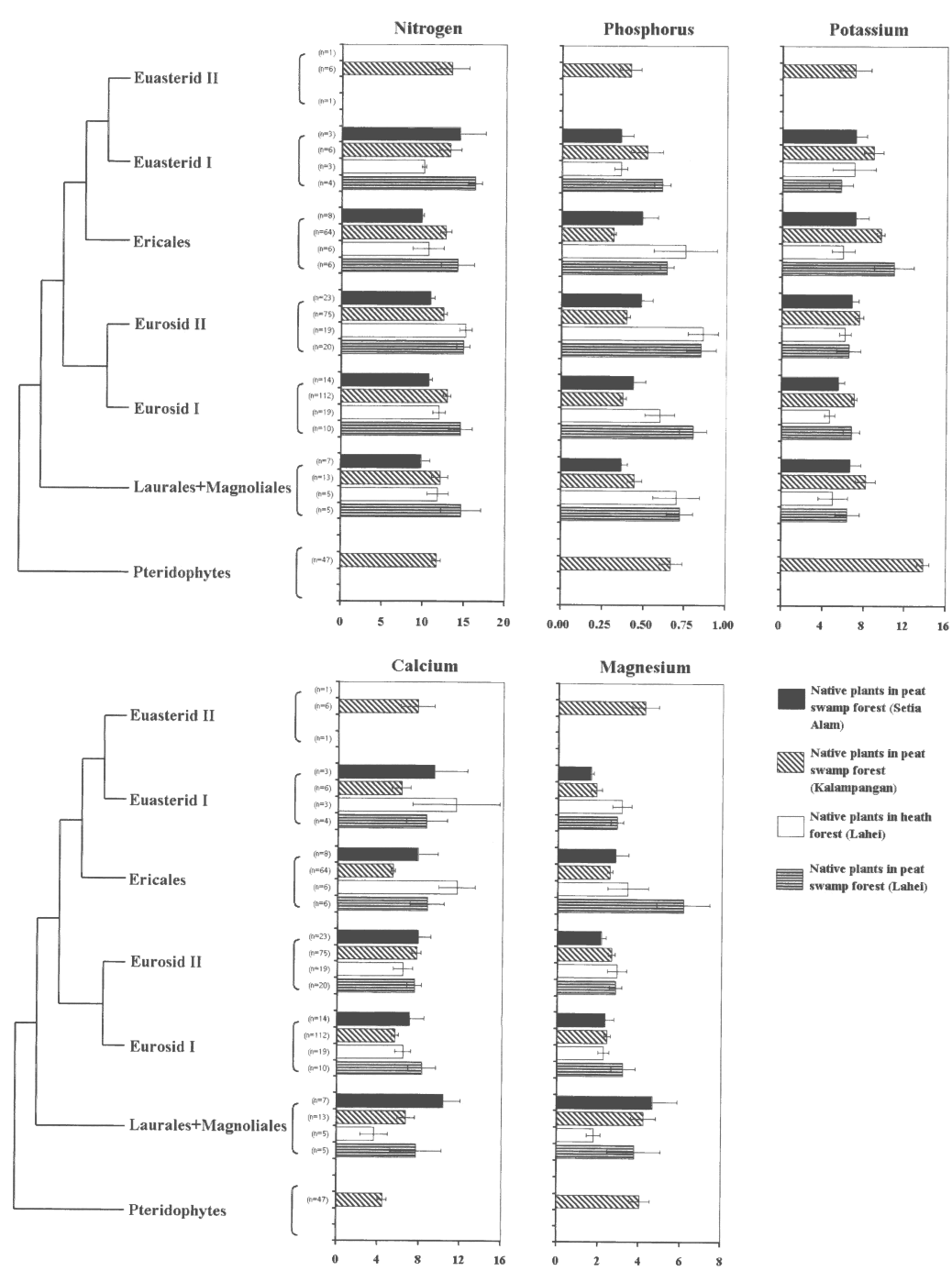

Fig. 6. Mean concentrations of $\mathrm{N}, \mathrm{P}, \mathrm{K}, \mathrm{Ca}$ and $\mathrm{Mg}\left(\mathrm{g} \mathrm{kg}^{-1}\right)$ in leaves of native plants from four sampling locations with respect to phylogenetic group. Bars indicate $S E$ value. 

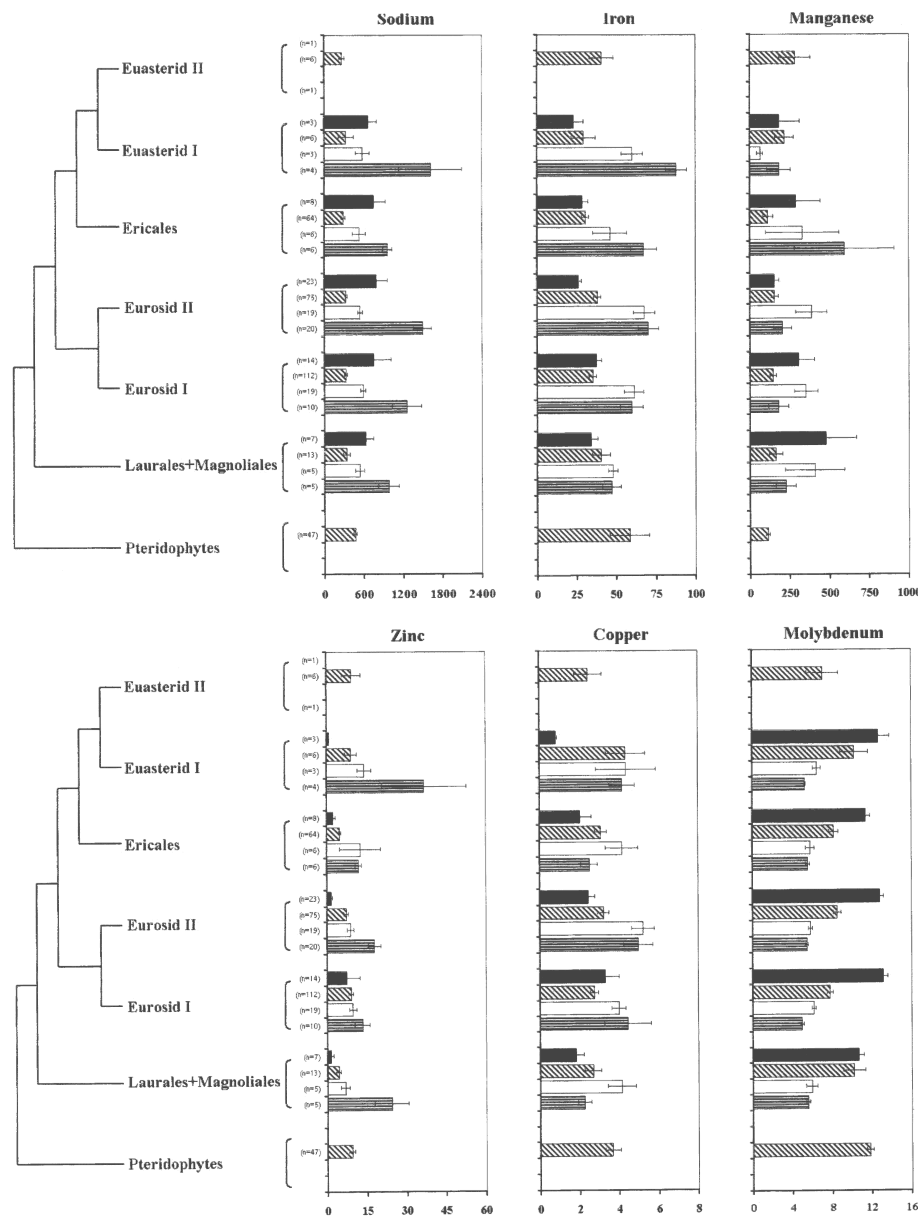

Molybdenum
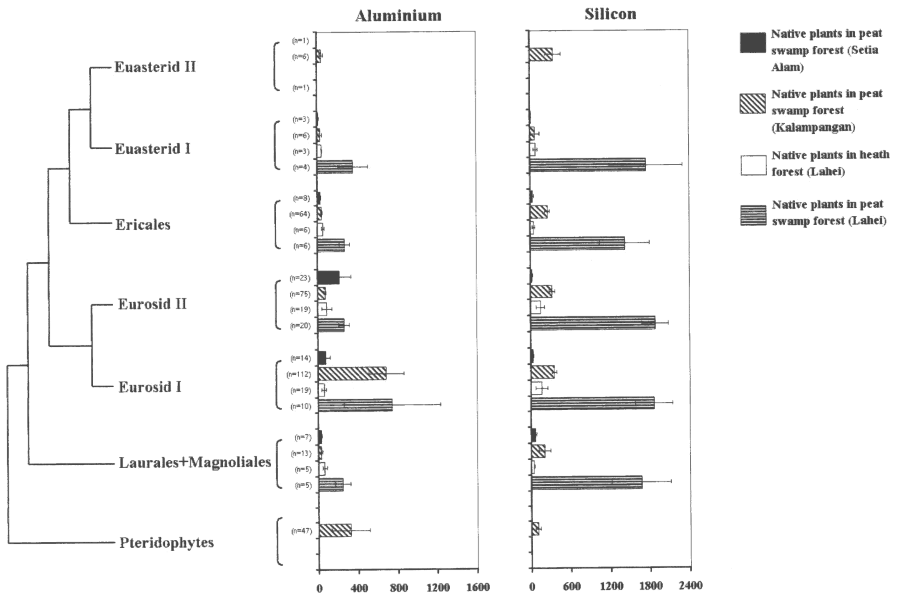

Native plants in peat
swamp forest (Lahel)

Fig. 7. Mean concentrations of $\mathrm{Na}, \mathrm{Fe}, \mathrm{Mn}, \mathrm{Zn}, \mathrm{Cu}, \mathrm{Mo}, \mathrm{Al}$ and $\mathrm{Si}\left(\mathrm{mg} \mathrm{kg}^{-1}\right)$ in leaves of native plants from four sampling locations with respect to phylogenetic group. Bars indicate $S E$ value. 
There was great specie specific variation in leaf elemental concentrations of different phylogenetic groups and sampling sites. Mean concentrations of the essential macro-elements $(\mathrm{N}, \mathrm{P}, \mathrm{K}, \mathrm{Ca}$, and $\mathrm{Mg}$ ) varied widely among sampling sites, but were relatively less divergent between phylogenetic groups. However, mean concentrations of the micro-elements ( $\mathrm{Na}, \mathrm{Fe}, \mathrm{Mn}, \mathrm{Zn}, \mathrm{Cu}, \mathrm{Mo}, \mathrm{Al}$, and $\mathrm{Si}$ ) demonstrated a considerably high variation between all taxonomic groups and sampling sites. Native plants belonging to the Pteridophyte group showed a high accumulation of $\mathrm{K}$ in their leaves, whereas the Ericales plants of the peat swamp forest in Lahei showed a high accumulation of $\mathrm{Mg}$. Some recently evolved native plants, mainly of the Euasterid I, Ericales, Eurosid II, Eurosid I, and the Magnoliids group, seemed to accumulate particular micro-elements such as $\mathrm{Na}, \mathrm{Fe}, \mathrm{Mn}, \mathrm{Cu}, \mathrm{Mo}, \mathrm{Al}$, and Si. However, no particular group had especially excessive accumulation. Several taxa within the Eurosid I evolutionary group had a considerably high $\mathrm{Al}$ concentration in their leaves in plants of both the Lahei and Kalampangan peat swamp forests (Fig. 7).

\section{Effect of Site Variation on Leaf Elemental Concentrations}

Because the array of element concentrations in leaves may reflect the concentration ratios of elements in substrates, it is argued that the properties of individual elements in plants may influence plant traits. The possibility of site-specificity of elemental concentrations in the leaves of the native plants was investigated with respect to plant evolutionary groups (Figs. 8, 9, and 10). Native peat swamp forest at the Kalampangan site (K1\&3) was investigated for this comparison, because of its relatively greater abundance and diversity of plant species compared with the other sites.
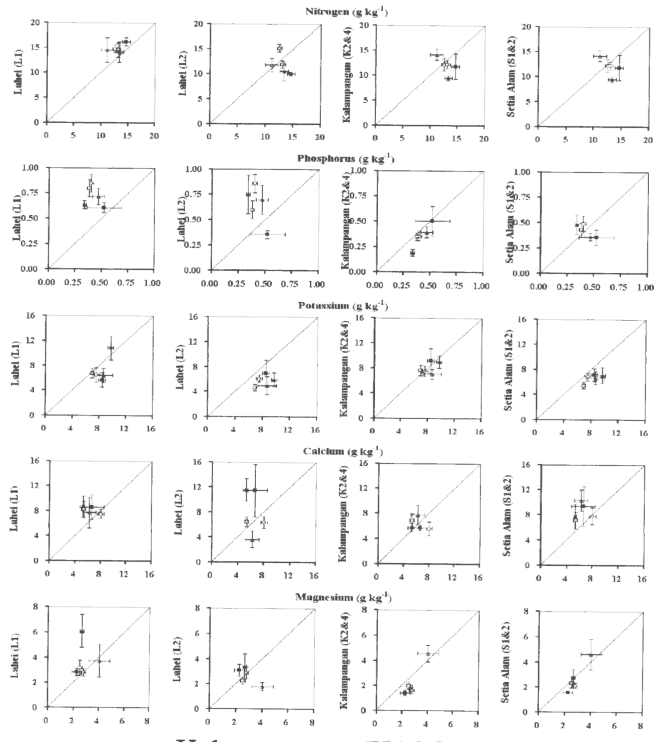

Kalampangan (K1\&3)

Fig. 8. Relationships of $\mathrm{N}, \mathrm{P}, \mathrm{K}, \mathrm{Ca}$ and $\mathrm{Mg}$ concentrations $\left(\mathrm{g} \mathrm{kg}^{-1}\right)$ in leaves of native plants with respect to phylogenetic group and sampling location. Bars indicate $S E$ value. L1: peat swamp forest in Lahei; L2: heath forest in Lahei; K1\&3: undisturbed peat swamp forest in Kalampangan; K2\&4: fire-damaged peat swamp forest in Kalampangan; S1\&2: peat swamp forest in Setia Alam. (O: Euasterid II; $\square$ : Euasterid I; $\triangle$ : Ericales; $\bigcirc$ : Eurosid II; $\square$ : Eurosid I; $\triangle$ : Magnoliales +Laurales). 

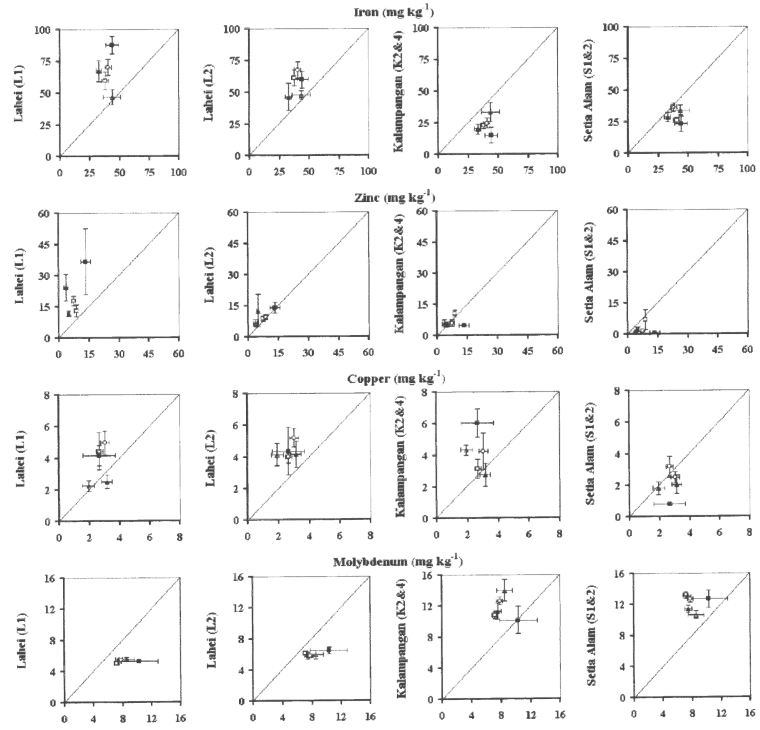

Kalampangan (K1\&3)

Fig. 9. Relationships of $\mathrm{Fe}, \mathrm{Zn}, \mathrm{Cu}$ and Mo concentrations $\left(\mathrm{mg} \mathrm{kg}^{-1}\right)$ in leaves of native plants with respect to phylogenetic group and sampling location. Bars indicate $S E$ value. L1: peat swamp forest in Lahei; L2: heath forest in Lahei; K1\&3: undisturbed peat swamp forest in Kalampangan; K2\&4: fire-damaged peat swamp forest in Kalampangan; S1\&2: peat swamp forest in Setia Alam. (O: Euasterid II; $\square$ : Euasterid I; $\triangle$ : Ericales; $\bigcirc$ : Eurosid II; $\square$ : Eurosid I; $\triangle$ : Magnoliales+Laurales).
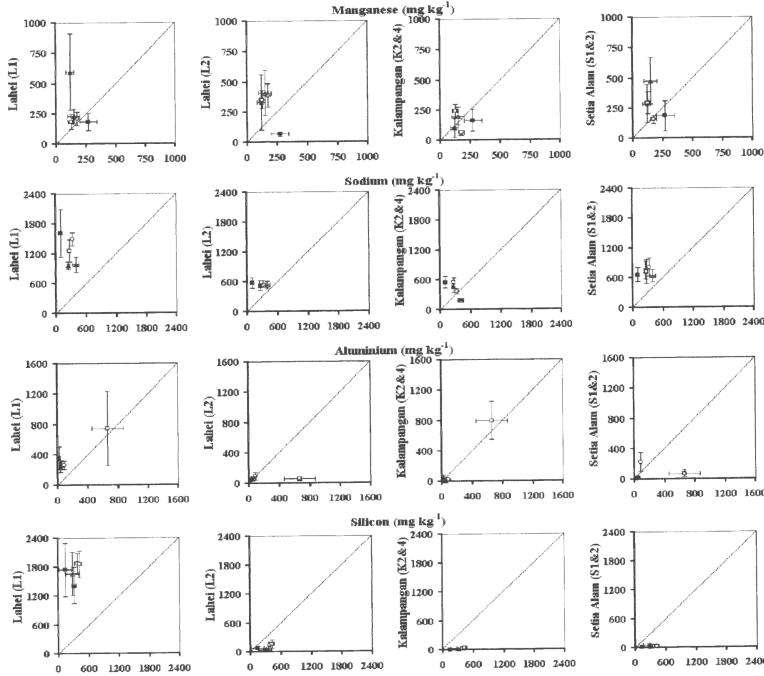

Kalampangan (K1\&3)

Fig. 10. Relationships of $\mathrm{Mn}, \mathrm{Na}, \mathrm{Al}$ and $\mathrm{Si}$ concentrations $\left(\mathrm{mg} \mathrm{kg}^{-1}\right)$ in leaves of native plants with respect to phylogenetic group and sampling location. Bars indicate $S E$ value. L1: peatswamp forest in Lahei; L2: heath forest in Lahei; K1\&3: undisturbed peat swamp forest in Kalampangan; K2\&4: fire-damaged peat swamp forest in Kalampangan; S1\&2: peat swamp forest in Setia Alam. (O: Euasterid II; $\square$ : Euasterid I; $\boldsymbol{\Delta}$ : Ericales; $\bigcirc$ : Eurosid II; $\square$ : Eurosid I; $\triangle$ : Magnoliales+Laurales). 
Mean concentrations of essential macro-elements in particular phylogenetic groups were less site-specific than micro-elements (Fig. 8). Most of the sites under peat swamp forest sites (L1, K2\&4, and S1\&2) showed no remarkable differences, with the exception of the heath forest (L2). However, the mean concentrations of $\mathrm{Ca}$ and $\mathrm{Mg}$ in the leaves from all study sites were highly site-specific (Fig. 8). In terms of micro-elements, the mineral concentrations were immensely affected by site heterogeneity (Figs. 9 and 10). In both the Kalampangan and Lahei peat swamp forests, plants of the Eurosid I group showed similar $\mathrm{Al}$ accumulation. It is therefore necessary to be aware that the species of the Eurosid I phylogeny have a preference to accumulate excessive concentrations of $\mathrm{Al}$ in their leaves.

\section{DISCUSSION}

Concentrations of various elements in the leaves of native plants growing on peat and sandy podzolic soils in tropical peat swamps and heath forests were examined in this study. Growth of native plants is generally limited by the availability of inorganic nutrients in soils and our results confirm that the concentrations of elements in plant leaves appear, to some extent, to be reflective of the site conditions. From a biochemical point of view, all plant species should require a similar quantity of nutrients to construct a given amount of tissue (Chapin 1980; Alonso \& Herrera 2001). However, differences do exist in tissue concentrations because of heterogeneous distribution of nutrients in soils and varying uptake efficiency in individual plants (Pugnaire 2001). Adaptation to varying nutrient availability in the substrates, therefore, has presumably led to disparities of nutrient concentrations between different native plants' organs, species and ecosystems. As shown in Appendix 1, the concentrations of individual elements differed widely between species and even between individuals of the same species, as well as between sampling sites. Because mineral nutrients have different functions within plants, their leaf concentrations may differ by orders of magnitude from essential macro-elements to trace elements (Appendix 1, Table 2 and 3).

Table 2 shows that the plants in natural systems demonstrate high inter- and intra-specific variability in nutrient concentrations as indicated by the coefficient of variation (CV) values of each element measured. Some native plant species show a preference for excessive accumulation of particular micro-elements, such as $\mathrm{Na}, \mathrm{Mn}, \mathrm{Al}$, and $\mathrm{Si}$; while certain species had very low concentrations of other micro-elements (especially $\mathrm{Zn}, \mathrm{Cu}$, and $\mathrm{Mo}$ ) in their leaves. However, notwithstanding the natural variability of nutrient concentrations, native plants grown in adverse environments (Table 2) show a relatively consistent concentration of nutrients in their leaves.

The chemical properties of the soils within the study sites (Table 1) are characterized by a very low availability of most nutrients, particularly $\mathrm{Cu}, \mathrm{Zn}$, and $\mathrm{Mn}$. This is probably related to the conditions of peat and sandy podzolic soils, in which nutrients are profoundly limited. Under ideal conditions, the amount of nutrients available in a medium correspond proportionally to the amount of nutrients taken up by the plants (Markert 1996). However, this is not the case in adverse conditions, as observed in this study. Thus, though the physiological mechanism is still unclear, it is assumed that the native plants have developed an efficient strategy enabling them to grow with only limited resources on the highly acidic soils of the peat swamps and heath forests. Mineral element concentrations in plant leaves are variable, not genetically predetermined, and the ability to grow with both low and high accumulation of 
particular nutrients may be an important aspect of an individual plant's adjustment to its environment (Alonso \& Herrera 2001).

To examine the possible effects of environmental variability on mineral element concentrations in the leaves of the plants studied, a comparison was made between sampling sites (Table 3). It is shown that $\mathrm{Mg}$ and $\mathrm{Al}$ concentrations were not significantly affected by environmental variability. Yet, the mean concentrations of $\mathrm{Na}, \mathrm{Fe}, \mathrm{Zn}, \mathrm{Al}$, and $\mathrm{Si}$ in the leaves of plants of the peat swamp forest in Lahei (L1) were notably higher compared to the other sites. The accumulation of elements in plant tissues is a dynamic process, and therefore the element concentrations of individual plants of inter- or intra-species may vary considerably from one site to another (Verhoeven et al. 1996). It has widely been acknowledged that mineral nutrients have various functions within plants, leading to differences in their concentrations over time (Pugnaire 2001).

Considering that the concentrations of nutrients in leaves are important indicators of the functioning of plant species in their ecosystem (Aerts \& Chapin 2000), it is necessary to understand the principal factors regarding elemental concentrations in the leaves of plants that may lead to further understanding the plant traits and/or natural groupings. Factor analysis (Fig. 2) specified that three elements, $\mathrm{Al}, \mathrm{Si}$, and $\mathrm{Na}$, were the main determinants of the characteristics of mineral elements in the leaves in this study. Among these three principal components, $\mathrm{Al}$ was the main component, followed by $\mathrm{Si}$ and Na. Figs. 3, 4 and 5 show the relationships between $\mathrm{Al}, \mathrm{Si}$ and $\mathrm{Na}$, as well as the relationships between these three elements and the other elements. However only Al has clear element interrelationships for each plant group. It is apparent that all the native plants are clearly separated into three groups with relatively low (first group), moderate (second group) and notably high (third group), leaf $\mathrm{Al}$ concentrations (Fig. 3). The third group was dominated by the species C. rotundatus (data not shown). It is evident that $\mathrm{Al}$-accumulating species (the third group) are likely restricting the accumulation of other mineral elements in their leaves, whereas non Al-accumulating species (the first and second group) tend to accumulate other mineral elements in their leaves. Seemingly, Al accumulating species have developed efficient mechanisms to utilize small amounts of essential elements in order to grow in the nutrient-limited soils of peat swamps and heath forests, though a specific explanation of this adaptation mechanism remains vague (Wanatabe \& Osaki 2002).

From these results, we conclude that $\mathrm{Al}, \mathrm{Si}$, and $\mathrm{Na}$ are likely the most important micro elements for the many native plants well-adapted to peat and podzolic sandy soils. In a study of several plant species well-adapted to temperate and tropical acid soils, Osaki et al. (1997) found Al to be beneficial to plant growth. In this study, we also found an antagonistic relationship between $\mathrm{Al}$ and $\mathrm{Na}$, and a synergistic interaction between $\mathrm{Al}$ and $\mathrm{Si}$, particularly in native plant species that have high concentrations of $\mathrm{Al}$ and $\mathrm{Si}$ in their leaf tissue. An antagonistic relationship between the concentrations of $\mathrm{Al}$ and $\mathrm{Na}$ was reported by Osaki et al. (1998) as an adaptation strategy of plants in nutrient poor, acidic tropical soils. Meanwhile, there is a possibility that there is a synergistic relationship between $\mathrm{Al}$ and $\mathrm{Si}$ concentrations in certain plants in which $\mathrm{Si}$ alleviates the toxic effects of $\mathrm{Al}$ on plants (Hodson and Evans 1995; Cocker et al. 1998; Masunaga et al. 1998). In their study on the relationship between $\mathrm{Al}$ and Si accumulation in Faramea marginata (family Rubiaceae), Britez et al. (2002) found a positive correlation between $\mathrm{Al}$ and $\mathrm{Si}$ concentrations and also that these two elements showed a similar distribution in leaf and stem tissues. It was also reported that the $\mathrm{Al}$ and $\mathrm{Si}$ elution patterns were similar to those of aluminum silicate. These results indicate a formation of an Al-Si complex occurred in 
the shoot tissues of $F$. marginata, which may be related to the internal Al detoxification mechanism. Silicon has also been demonstrated to inhibit $\mathrm{Al}$ penetration into the root cortex of Sorghum bicolor, suggesting that $\mathrm{Si}$ forms a complex with $\mathrm{Al}$ in either the media or roots and contributes to the detoxification of $\mathrm{Al}$ (Hodson \& Sangster 1993). In a forest ecosystem, such as in the peat swamps and heath forests, $\mathrm{Al}$ is present in plant tissue and thus obviously taken up by the plant. Through litterfall and root dieback, plants redistribute $\mathrm{Al}$ into the soil by way of decomposition (Rustad \& Cronan 1989). As soil organic matter is originates from non-living plant materials, such as litterfall and root dieback, it is presumable that $\mathrm{Al}$ in peat soil forms a complex with soluble organic matter. $\mathrm{Al}$ in this form is not toxic to plants (Kinraide 1991) and complexation of $\mathrm{Al}$ by organic matter appears to be a very important mechanism of Al detoxification of soil solution (Kochian 1995). In addition, during decomposition of plant debris, a whole range of organic compounds are released from the debris and/or synthesized by decomposer microorganisms (Haynes \& Mokolobate 2001). Al can bind strongly to many of these compounds (Stevenson \& Vance 1989). Therefore, it is evident that various native plants in humid tropical regions with strongly acidic soil can vigorously grow with a high accumulation of $\mathrm{Al}$ in their leaves (cf. Osaki et al. 1995 \& 1997).

Although the accumulation of an element in plant tissues does not necessarily mean that it plays a prominent physiological role (Bargagli 1998), to some extent it may indicate that plants respond differently to environmental variability (Alonso \& Herrera 2001), and therefore the accumulative behavior of a plant may also have genetically predetermined origins (Markert 1996). The patterns of mineral element accumulation in the leaves of native plants in this study were elucidated according to plant evolutionary classification. There was considerable specie-specific and site-specific variation in elemental acquisition (Figs. 6 and 7). The mean concentrations of essential macro-elements were less divergent between phylogenetic groups. In contrast, the mean concentrations of micro-elements varied markedly among taxonomic groups and sites. A strong relationship between leaf nutrient concentration and habitat and phylogeny was reported in several taxa of herbaceous flora (Thompson et al. 1997). Taxa that are restricted to fertile, lowland habitats (e.g. Chenopodium, Urticaceae) tend to have nutrient-rich foliage, whereas those that are mostly confined to upland, infertile habitats (e.g. Cyperaceae, Ericaceae) have nutrient-poor foliage. Thompson et al. (1997) therefore argued that leaf nutrient concentrations are essentially a specie-specific trait. In this study, native plants belonging to the Eurosid I phylogeny group had very high $\mathrm{Al}$ accumulation in their leaves in both the Kalampangan and Lahei peat swamp forest (Fig. 7). In the Lahei peat swamp forest, $\mathrm{Al}$ accumulator species were recorded for only one taxon (Euphorbiaceae), whereas in Kalampangan, it was recorded for two taxa (Anisophylleaceae and Lycopodiaceae). Of these taxa, C. rotundatus (Anisophylleaceae) was the species most widely distributed, particularly in the fire-damaged area. In a review of $\mathrm{Al}$ accumulation in angiosperms, Jansen et al. (2002) reported that the species of the woody plant genus Combretocarpus are Al accumulators. As $\mathrm{Al}$ in peat soil is presumably bound into organic matter as chelate compounds, it is posited that $C$. rotundatus and other Al-accumulating species have developed their particular ability to absorb and accumulate Al through adaptation mechanisms in adverse environments. Such mechanisms are thought to involve the formation of a complex with an $\mathrm{Al}$ ion, as well as intracellular and tissue compartmentalization (Britez et al. 2002; Watanabe \& Osaki 2002).

Both from an ecological and a nutrient physiological point of view, chemical characterization of ecosystems provides important information on the fate of elements in different systems. Thus, the 
pattern of nutrient accumulation could be shaped by environmental and evolutionary factors. Heterogeneity of the sites was examined in this study in relation to elemental concentrations, and the results show that environmental elemental concentrations have a significant impact on leaf element concentrations within each taxonomic group (Figs. 8, 9, and 10). Although the concentrations of $\mathrm{Mg}$ and $\mathrm{Ca}$ in plant leaves tended to be site-specific, as also reported by Alonso \& Herrera (2001), this may not occur consistently in the case of habitats with a larger variety of native plant species. It is argued that the main factors influencing mineral element concentrations are the inherent characteristics of each individual specie. This is mainly because native plants can absorb and accumulate nutrients selectively and maintain a balance of intercellular element concentrations to optimize their growth in spite of low nutrient availability (Garten 1976). Apparently, during their subsequent growth, native plants adjust their elemental composition with respect to the nutritional status of their environment (soil). Also the native plant species that are adapted to nutrient limited forests have developed adaptation strategies which include acquiring high concentrations of $\mathrm{Al}, \mathrm{Si}$, and $\mathrm{Na}$ in their leaves. This information is considered necessary for the selection of appropriate plant species to rehabilitate damaged peat swamps and heath forests. However, further research is needed to clarify physiological aspects of plant adaptation mechanisms, especially plant species that are considered $\mathrm{Al}$ accumulators.

ACKNOWLEDGMENTS We express our gratitude to Professor Mitsuru OSAKI for his invaluable support and encouragement. The assistance of our colleagues at Palangka Raya University during field sampling is greatly acknowledged. We also thank two anonymous reviewers for their critical comments. This research was supported by a research grant from the Japan Society for the Promotion of Science (JSPS) under a Core University Program between Hokkaido University, Japan and R \& D Center of Biology, LIPI, Indonesia.

\section{REFERENCES}

Aerts, R. \& Chapin III, F. S. 2000. The mineral nutrition of wild plants revisited: a re-evaluation of processes and patterns. Advances in Ecological Research 30:1-67.

Alonso, C. \& Herrera, C.M. 2001. Patterns made patterns: variation and covariation of leaf nutrient concentrations within and between populations of Prunus mahaleb. New Phytologist 150: 629-640.

Artiningsih, T. 1999. Decomposition of organic matter in peat soil by fungi. Environmental Conservation and Land Use Management of Wetland Ecosystem in Southeast Asia (Annual Report for April 1998 - March 1999 of the Core University Program between Hokkaido University, Japan and R\&D Center of Biology, LIPI, Indonesia), pp. 229.

Attiwill, P. M. 1980. Nutrient cycling in a Eucalyptus obliqua (L'Hérit) forest (IV): nutrient uptake and nutrient return. Australian Journal of Botany 28: 199-222.

Bargagli, R. 1998. Trace elements in terrestrial plants: an ecophysiological approach to biomonitoring and biorecovery, pp. 1-47 Spring-Verlag Berlin Heidelberg and R.G. Landes Company, Georgetown, TX, USA.

Britez, R.M., Watanabe, T., Jansen, S., Reissmann, C.B. \& Osaki, M. 2002. The relationship between aluminum and silicon accumulation in leaves of Faramea marginata (Rubiaceae). New Phytologist 156: $437-444$. 
Chapin, F. S. III. 1980. The mineral nutrition of wild plants. Annual Review of Ecology and Systematics 11: 233-260.

Chapin, F. S. III. 1988. Ecological aspects of plant mineral nutrition. Advances in Mineral Nutrition 3: 61-191.

Chase, M. W., Soltis, D. E., Olmstead, R. G., Morgan, D., Les, D. H., Mishler, B. D., Duvall, M. R., Price, R. A., Hills, H. G., Qiu, Y. L., Kron, K. A., Rettig, J. H., Conti, E., Palmer, J. D., Manhart, J. R., Sytsma, K. J., Michaels, H. J., Kress, W. J., Karol, K. G., Clark, W. D., Hedren, M., Gaut, B. S., Jansen, R. K., Kim, K. J., Wimpee, C. F., Smith, J. F., Furnier, G. R., Strauss, S. H., Xiang, Q. Y., Plunkett, G. M., Soltis, P. S., Swensen, S. M., Williams, S. E., Gadek, P. A., Quinn, C. J., Eguiarte, L. E., Golenberg, E., Learn Jr., G. H., Graham, S. W., Barrett, S. C. H., Dayanandan, S. \& Aldert, V. A. 1993. Phylogenetics of seed plants: an analysis of nucleotide sequences from the plasmid gene rbcL. Annals of the Missouri Botanical Garden 80: 528-580.

Cocker, K. M., Evans, D. E. \& Hodson, M. J. 1998. The amelioration of aluminum toxicity by silicon in higher plants: solution chemistry or an in planta mechanism? Physiologia Plantarum 104: 608-614.

Garten, C. T. 1976. Correlation between concentrations of elements in plants. Nature 261: 686-688.

Grime, J. P., Thompson, K., Hunt, R., Hodgson, J. G., Cornelissen, J. H. C. \& Rorison, I. H. 1997. Integrated screening validates primary axes of specialization in plants. Oikos 79: 259-281.

Hamilton, E. I. 1995. State of the art of trace element determinations in plants matrices: determination of the chemical elements in plant matrices, an overview. The Science of the Total Environment 176: 3-14.

Haynes, R.J. \& Mokolobate, M.S. 2001. Amelioration of Al toxicity and P deficiency in acid soils by additions of organic residues: a critical review of the phenomenon and the mechanisms involved. Nutrient Cycling in Agroecosystems 59: 47-63.

Hodson, M. J. \& Evans, D. E. 1995. Aluminum/silicon interactions in higher plants. Journal of Experimental Botany 46: 161-171.

Jansen, S., Broadley, M., Robbrecht, E. \& Smets, E. 2002. Aluminum hyperaccumulation in angiosperms: a review of its phylogenetic significance. The Botanical Review 68: 235-269.

Kinraide, T.B. 1991. Identify of the rhizotoxic aluminum species. Plant and Soil 134: 167-178.

Kochian, L. V. 1995. Cellular mechanisms of aluminum toxicity and resistance in plants. Annual Review of Plant Physiology and Plant Molecular Biology 46: 237-260.

Markert, B. 1996. Instrumental element and multi-element analysis of plant samples: methods and applications (Translated by B. Haderlie), pp 9-21. John Wiley \& Sons, Chichester.

Masunaga, T., Kubota, D., Hotta, M. \& Wakatsuki, T. 1997. Nutritional characteristics of mineral elements in tree species of tropical rain forest, West Sumatra, Indonesia. Soil Science and Plant Nutrition 43: 405-418.

Masunaga, T., Kubota, D., Hotta, M. \& Wakatsuki, T. 1998. Mineral composition of leaves and bark in aluminum accumulators in a tropical rain forest in Indonesia. Soil Science and Plant Nutrition 44: 347-358.

Mizuno, N. \& Minami, M. 1980. The use of $\mathrm{H}_{2} \mathrm{SO}_{4-} \mathrm{H}_{2} \mathrm{O}_{2}$ for destruction of plants matter as a preliminary to determination of N, K, Mg, Ca, Fe, Mn. Jpn. Journal of Soil Science and Plant Nutrition 51: 418420 (in Japanese with English Summary).

Osaki, M., Sittibush, C. \& Nuyim, T. 1995. Nutritional characteristics of wild plants grown in peat and 
acid sulfate soils distributed in Thailand and Malaysia. In: Vijarsorn, P., Suzuki, K., Kyuma, K., Wada, E., Nagano, T. \& Takai, Y. (eds.). A tropical swamp forest ecosystem and its greenhouse gas emission, pp 63-67. Nodai Research Institute Tokyo University of Agriculture, Tokyo.

Osaki, M., Watanabe, T. \& Tadano, T. 1997. Beneficial effect of aluminum on growth of plants adapted to low pH soil. Soil Science and Plant Nutrition 43: 551-563.

Osaki, M., Watanabe, T., Ishizawa, T., Nilnond, C., Nuyim, T., Shinano, T., Urayama, M. \& Tuah, S. J. 2003. Nutritional characteristics of the leaves of native plants growing in adverse soils of humid tropical lowlands. Plant Foods for Human Nutrition: (in press).

Osaki, M., Watanabe, T., Ishizawa, T., Nilnond, C., Nuyim, T., Sittibush, C. \& Tadano, T. 1998. Nutritional characteristics in leaves of native plants grown in acid sulfate, peat, sandy podzolic, and saline soils distributed in Peninsular Thailand. Plant and Soil 201: 175-182.

Pampasit, S., Khamyong, S., Breulmann, G., Ninomiya, I. \& Ogino, K. 2000. Elements concentrations in tree species of tropical hill evergreen forest, Northern Thailand. Tropics 9: 287-308.

Polak, B. 1975. Character and occurrence of peat deposits in the Malaysian tropics. Pp. 71-81 in G. J. Bartstra \& Caspare, W. A. (eds). Modern quaternary research in Southeast Asia. A.A. Belkema, Rotterdam.

Proctor, J. 1987. Nutrient cycling in old secondary rainforests. Applied Geography 7: 135-152.

Pugnaire, F.I. 2001. Variability of inorganic nutrient concentrations in leaves. New Phytologist 150: 499507.

Radjagukguk, B. 1997. Peat soils of Indonesia: location, classification and problems for sustainability. In Rieley, J. O. \& Page, S. E. (eds.). Biodiversity and Sustainability of Tropical Peatlands. Proceedings of the International Symposium on Biodiversity, Environmental Importance and Sustainability of Tropical Peat and Peatlands. Samara Publishing Limited, UK.

Rao, I. M., Zeigler, R. S., Vera, R. \& Sarkarung, S. 1993. Selection and breeding for acid-soil tolerance in crops. BioScience 43: 455-465.

Rustad, L.E. \& Cronan, C.S. 1989. Cycling of aluminum and nutrients in litterfall of a red spruce (Picea rubens Sarg.) stand in Maine. Canadian Journal of Forest Research 19: 18-23.

Sirirattanakorn, S. 1999. Leaf functional and leaf demographic studies on productivity of important species in tropical dry evergreen forest and deciduous dipterocarp forest at Sakaerat, Changwat Nakhon Ratchasima. Dissertation submitted to the Graduate School, Kasetsart University, Thailand, pp. 242.

Soltis, P. S., Soltis, D. E. \& Chase, M. W. 1999. Angiosperm phylogeny inferred from multiple genes as a tool for comparative biology. Nature 402: 402-404.

Stevenson, F.J. \& Vance, G.F. 1989. Naturally occurring aluminum-organic complexes. In: Sposito, G. (ed.) The environmental chemistry of aluminum, pp 117-146. CRC Press, Boca Raton.

Suzuki, E., Kohyama, T., Simbolon, H., Haraguchi, A., Tsuyuzaki, S. \& Nishimura, T. 1998. Vegetation of kerangas and peat swamp forests in Lahei, Central Kalimantan. Environmental Conservation and Land Use Management of Wetland Ecosystem in Southeast Asia (Annual Report and Proceedings for International Workshop in Palangka Raya, Central Kalimantan, Indonesia, 6-9 August 1997). Core University Program between Hokkaido University, Japan and R\&D Center of Biology, LIPI, Indonesia), pp. 1-10

The Angiosperm Phylogeny Group. 1998. An ordinal classification for the families of flowering plants. 
Annals of the Missouri Botanical Garden 85: 531-553.

Thompson, K., Parkinson, J. A., Band, S. R. \& Spencer, R. E. 1997. A comparative study of leaf nutrient concentrations in a regional herbaceous flora. New Phytologist 136: 676-689.

Watanabe, T. \& Osaki, M. 2002. Mechanisms of adaptation to high aluminum condition in native plant species growing in acid soils: a review. Communications in Soil Science and Plant Analysis 33: 1247-1260.

Watson, L. \& Dallwitz, M. J. 1992 onwards. The families of flowering plants: descriptions, illustrations, identification, and information retrieval. Version: $14^{\text {th }}$ December 2000. http://biodiversity.uno. edu/delta/.

Received Sep. 6, 2002

Accepted Mar. 18, 2003 
Appendix 1. Concentrations of mineral elements in the leaves of native plants from tropical peat swamps and heath forests of Central Kalimantan, Indonesia.

\begin{tabular}{|c|c|c|c|c|c|c|}
\hline $\begin{array}{l}\text { Phylogenet } \\
\text { group* }\end{array}$ & Family & Species & Form & $\mathrm{N}$ & $\mathbf{P}$ & $\mathbf{K}$ \\
\hline & & & & & & $\left.\mathrm{g} \mathrm{kg}^{-1}\right)$ \\
\hline $\begin{array}{l}\text { Euasterid II } \\
\text { Euasterid I }\end{array}$ & Aquifoliaceae & Iex cymosa BI. & tree & 10.4 & 0.2 & \\
\hline $\begin{array}{l}\text { Euasterid I } \\
\text { Euasterid I }\end{array}$ & Oleaceae & Chiomanthus ramiflorus Roxb. & tree & 17.5 & 0.7 & $\begin{array}{l}5.5 \\
8.4\end{array}$ \\
\hline $\begin{array}{l}\text { Euasterid I } \\
\text { Euasterid I }\end{array}$ & Oleaceae & Chionanthus ramiflonus Roxb. & tree & 15.5 & 0.5 & 3.3 \\
\hline $\begin{array}{l}\text { Euasterid I } \\
\text { Euasterid I }\end{array}$ & Rubiaceae & Timonius flavescens (Jack) Baker & tree & 17.6 & 0.6 & 6.8 \\
\hline $\begin{array}{l}\text { Euasterid I } \\
\text { Ericales }\end{array}$ & Rubiaceae & Timonius flavescens (Jack) Baker & tree & $\begin{array}{l}14.3 \\
9.8\end{array}$ & 0.5 & 4.2 \\
\hline $\begin{array}{l}\text { Ericales } \\
\text { Ericales }\end{array}$ & Ebenaceae & Diospyros hermaphroditica (Zoll.) Bakh. & $\begin{array}{l}\text { tree } \\
\text { tree }\end{array}$ & $\begin{array}{r}9.8 \\
16.9\end{array}$ & 0.6 & $\begin{array}{l}13.6 \\
18.5\end{array}$ \\
\hline $\begin{array}{l}\text { Ericales } \\
\text { Ericales }\end{array}$ & Ebenaceae & 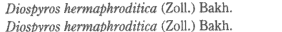 & tree & $\begin{array}{l}16.9 \\
15.5\end{array}$ & 0.7 & $\begin{array}{l}18.5 \\
11.3\end{array}$ \\
\hline $\begin{array}{l}\text { Ericales } \\
\text { Ericales }\end{array}$ & $\begin{array}{l}\text { Ebbancaea } \\
\text { Ebenaceae }\end{array}$ & 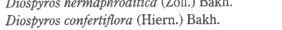 & tree & 19.7 & 0.7 & 6.9 \\
\hline Ericales & Ebenaceae & Diospyros confertiflora (Hiern.) Bakh. & tree & 16.3 & 0.6 & 5.6 \\
\hline $\begin{array}{l}\text { Ericales } \\
\text { Eurosid II }\end{array}$ & Tetrameristaceae & Tetramerista glabra Miq. & tree & 6.6 & 0.5 & 9.2 \\
\hline $\begin{array}{l}\text { Eurosid II } \\
\text { Eurosid II }\end{array}$ & Anacardiaceae & Buchanania sessifolia Bl. & tree & 20.8 & 0.9 & 5.4 \\
\hline $\begin{array}{l}\text { Eurosid II } \\
\text { Eurosid II }\end{array}$ & Anacardiaceae & Buchanania sessifolia Bl. & tree & 20.7 & 2.3 & 25.6 \\
\hline $\begin{array}{l}\text { Eurosid II } \\
\text { Eurosid II }\end{array}$ & Anacardiaceae & Buchanania sessiffolia Bl. & tree & 16.4 & 1.3 & 11.0 \\
\hline Eurosid II & Anacardiaceae & Semecarpus longifolius Bl. & tree & 14.3 & 0.7 & 4.9 \\
\hline Eurosid II & Burseraceae & Canarium hirsutum Willd. & tree & 17.8 & 1.0 & 5.5 \\
\hline $\begin{array}{l}\text { Eurosid II } \\
\text { Eursosid I }\end{array}$ & Burseraceae & & tree & $\begin{array}{r}8.5 \\
100\end{array}$ & 0.8 & 3.3 \\
\hline $\begin{array}{l}\text { Eurosid II } \\
\text { Eurosid II }\end{array}$ & $\begin{array}{l}\text { Dipterocarpaceae } \\
\text { Dinterocarasceae }\end{array}$ & $\begin{array}{l}\text { Cotylebobiam melanoxylon Pierre } \\
\text { Shorea balangeran (Korth.) Burk. }\end{array}$ & $\begin{array}{c}\text { tree } \\
\text { tree }\end{array}$ & $\begin{array}{l}10.0 \\
17.8\end{array}$ & 0.7 & $\begin{array}{l}4.0 \\
32\end{array}$ \\
\hline $\begin{array}{l}\text { Eursosid II } \\
\text { Eurosid II }\end{array}$ & $\begin{array}{l}\text { Dipterocarpaceae } \\
\text { Dipterocarpaceae }\end{array}$ & $\begin{array}{l}\text { Shorea b balangegran n (Korth.) Burk. } \\
\text { Shorea balangeran (Korth.) Burk. }\end{array}$ & $\begin{array}{l}\text { tree } \\
\text { tree }\end{array}$ & 16.1 & 0.9 & 3.2 \\
\hline Eurosid II & Dipterocarpaceae & Shorea balangeran (Korth.) Burk. & $\begin{array}{l}\text { tree } \\
\text { tree }\end{array}$ & 15.3 & 0.9 & 4.7 \\
\hline Eurosid II & Dipterocarpaceae & Vatica rassak (Korth.) Bl. & $\begin{array}{l}\text { Whee } \\
\text { tree }\end{array}$ & 12.5 & 0.8 & 4.7 \\
\hline Eurosid II & Myrtaceae & Syzygium havilandii Merr. & tree & 17. & 0.6 & 4.7 \\
\hline Eurosid II & Myrtaceae & Syzygium polyantha Wight. & tree & 13.2 2 & 0.7 & 4.6 \\
\hline & Myrtaceae & 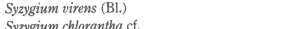 & $\begin{array}{c}\text { tree } \\
\text { trae }\end{array}$ & 9.4 & 0.5 & 2.2 \\
\hline Eurosid II & Myrtaceae & $\begin{array}{l}\text { Syyygium c chloranthac c. } \\
\text { Tristaniopsis whitiana Griffith. }\end{array}$ & $\begin{array}{l}\text { tree } \\
\text { tree }\end{array}$ & 11.3 & 0.6 & 13.6 \\
\hline $\begin{array}{l}\text { Eurosid II } \\
\text { Eurosid II }\end{array}$ & $\begin{array}{l}\text { Myrtaceae } \\
\text { Rutcaeae }\end{array}$ & 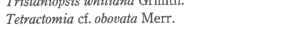 & $\begin{array}{l}\text { tree } \\
\text { tree }\end{array}$ & $\begin{array}{l}13.2 \\
17.4\end{array}$ & $\begin{array}{l}0.7 \\
0.4\end{array}$ & $\begin{array}{l}4.7 \\
5.1\end{array}$ \\
\hline $\begin{array}{l}\text { Eurostai II } \\
\text { Eurosid II }\end{array}$ & Sapindaceae & Nephelium cf, maingayi Hiern. & tree & 14.0 & 0.8 & 4.3 \\
\hline Eurosid II & $\begin{array}{l}\text { Tiliaceae } \\
\text { The }\end{array}$ & Pentace borneensis Pierre & tree & 19.7 & 1.1 & 8.9 \\
\hline Eurosid II & Tiliaceae & Pentace bormeensis Pierre & tree & 105 & 0.8 & 6.0 \\
\hline Eurosid I & Caesalpiniaceae & Dialium patens Bak. & tree & 11.7 & 0.6 & 4.5 \\
\hline Eurosid I & Caesalpiniaceae & Dialium patens Bak. & tree & 14.5 & 0.9 & 7.1 \\
\hline Eurosid I & Caesalpiniaceae & Koompassia malaccensis Maing. Ex. Benth. & tree & 18.1 & 1.0 & 6.1 \\
\hline Eurosid I & Chrysobalanaceae & $\begin{array}{l}\text { Parastemon urophyllus (A.DC,) } \\
\text { (a) }\end{array}$ & tree & 13.1 & 1.0 & 11.8 \\
\hline Eurosid I & Clusiaceae & $\begin{array}{l}\text { Calophyllum hosei Ridley } \\
\text { Garcinia dioica Bl. }\end{array}$ & tree & 8.8 & 0.5 & 6.4 \\
\hline Eurosid I & $\begin{array}{l}\text { Clusiaceae } \\
\text { Euphorbiaceae }\end{array}$ & & $\begin{array}{l}\text { tree } \\
\text { tree }\end{array}$ & 15.4 & 0.7 & 6.0 \\
\hline $\begin{array}{l}\text { Eurosid I I } \\
\text { Eursosid I }\end{array}$ & $\begin{array}{l}\text { Euphorbiaceae } \\
\text { Euphorbiaceae }\end{array}$ & $\begin{array}{l}\text { Baccacartaea macrocarpa a (Milo, Muell. Arg. } \\
\text { Cleistanthus maingayi Hook.f. }\end{array}$ & $\begin{array}{l}\text { tree } \\
\text { tree }\end{array}$ & $\begin{array}{l}14.0 \\
168\end{array}$ & 0.6 & 7.6 \\
\hline $\begin{array}{l}\text { Eurosial I } \\
\text { Eurosid I }\end{array}$ & Euphorbiaceae & $\begin{array}{l}\text { Celistatithus mangayay Hook.1. } \\
\text { Antidesma montanum } \mathrm{Bl} \text {. }\end{array}$ & e & ${ }_{24 .}^{16.8}$ & 0.7 & 9.6 \\
\hline Eurosid I & Ixonanthaceae & 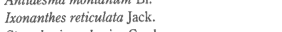 & e & $\begin{array}{r}24.4 \\
8.8\end{array}$ & $\begin{array}{l}1.4 \\
0.6\end{array}$ & $\begin{array}{l}5.4 \\
3.1\end{array}$ \\
\hline Core Eudicots & Olacaceae & Strombosia ceylanica Ga & ee & 15.1 & 0.8 & 7.7 \\
\hline Magnoliales & Annonaceae & is Hook.fi. \& Thoms. & tree & 12.3 & 0.7 & 7.0 \\
\hline Laurales & $\begin{array}{l}\text { Lauraceae } \\
\text { Lurracaee }\end{array}$ & $\begin{array}{l}\text { Actinodaphre bomerense Meisn. } \\
\text { Litsen ochracea (Bl.) Boerl. }\end{array}$ & tree & 10.4 & 0.5 & 3.6 \\
\hline $\begin{array}{l}\text { Laurales } \\
\text { Magnoliales }\end{array}$ & $\begin{array}{l}\text { Lauraceae } \\
\text { Myristiceae }\end{array}$ & $\begin{array}{l}\text { Litsea a chracea (B.) Boerl. } \\
\text { Gymnacranthera eugenifolia (A.DC.) Sinclair. }\end{array}$ & $\begin{array}{l}\text { tree } \\
\text { tree }\end{array}$ & $\begin{array}{l}24.0 \\
24.1\end{array}$ & $\begin{array}{l}0.8 \\
0.9\end{array}$ & $\begin{array}{r}6.5 \\
10.3\end{array}$ \\
\hline Magnoliales & Myristicaeae & $\begin{array}{l}\text { Gymnacranthera eugenifolia (A.DC.) Sinclair. } \\
\text { Knema glauca (Bl.) Warb. }\end{array}$ & $\begin{array}{l}\text { tree } \\
\text { tree }\end{array}$ & $\begin{array}{l}1.1 \\
12.1\end{array}$ & 0.6 & 4.5 \\
\hline & & & & & & \\
\hline Euasterid I & Rubiaceae & pterocalyx Val. & tree & 9.7 & 0.3 & 9.4 \\
\hline Euasterid I & $\begin{array}{l}\text { Rubiaceae } \\
\text { Rubiccae }\end{array}$ & $\begin{array}{l}\text { Ixora havilandii Mert. } \\
\text { Timonius flavescens (Jack) Baker }\end{array}$ & tree & 9.7 & 0.4 & 8.7 \\
\hline $\begin{array}{l}\text { Euasterid I } \\
\text { Ericales }\end{array}$ & $\begin{array}{l}\text { Rubiaccae } \\
\text { Ebenaceae }\end{array}$ & $\begin{array}{l}\text { Timonius flavescens (Jack) Baker } \\
\text { Diospyyos hermaphroditica (Zoll.) Bakh. }\end{array}$ & $\begin{array}{l}\text { tree } \\
\text { tree }\end{array}$ & $\begin{array}{l}10.5 \\
10.2\end{array}$ & $\begin{array}{l}0.3 \\
0.4\end{array}$ & $\begin{array}{l}2.7 \\
3.8\end{array}$ \\
\hline $\begin{array}{l}\text { Encales } \\
\text { Ericales }\end{array}$ & Myrsinaceae & $\begin{array}{l}\text { Ardisia hevigata Blume } \\
\text { Alus }\end{array}$ & tree & 10.2 & 0.4 & $\begin{array}{l}2.0 \\
2.8\end{array}$ \\
\hline Ericales & Sapotaceae & Isomandra lanceolata Wight. & tree & 19.7 & 1.5 & 9.5 \\
\hline $\begin{array}{l}\text { Ericales } \\
\text { Eles }\end{array}$ & Sapotaceae & Palaquium leiocarpum Boerl. & tree & 7.7 & 0.5 & 4.2 \\
\hline Ericales & Sapotaceae & Payena endertii HJ Lam & tree & 8.4 & 1.1 & $\begin{array}{l}6.8 \\
8.5\end{array}$ \\
\hline Ericales & Theaceae & Ternstroemia coriaceae R. Scheffer. & $\begin{array}{l}\text { tree } \\
\text { tree }\end{array}$ & $\begin{array}{r}7.1 \\
13.9\end{array}$ & $\begin{array}{l}0.5 \\
1.1\end{array}$ & $\begin{array}{l}8.5 \\
7.6\end{array}$ \\
\hline $\begin{array}{l}\text { Eurosid II } \\
\text { Fursedif I }\end{array}$ & Anacardiaceae & 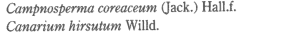 & $\begin{array}{l}\text { tree } \\
\text { tree }\end{array}$ & 15.6 & 1.1 & 5.7 \\
\hline $\begin{array}{l}\text { Eurosid II } \\
\text { Eursoid II }\end{array}$ & $\begin{array}{l}\text { Burseraceeae } \\
\text { Burseraceae }\end{array}$ & $\begin{array}{l}\text { Canarinum hirsutum Wild. } \\
\text { Canarizm hirsutum Wild. }\end{array}$ & tree & 16.2 & 0.7 & 5.4 \\
\hline $\begin{array}{l}\text { Eurosid II } \\
\text { Eurosid II }\end{array}$ & $\begin{array}{l}\text { Burseraceae } \\
\text { Burseraceae }\end{array}$ & garium sp. & tree & 10.0 & 0.5 & 3.0 \\
\hline $\begin{array}{l}\text { Eurosoid II } \\
\text { Eurosid II }\end{array}$ & Dipterocarpaceae & Shorea platycarpa Heim. & tree & 13.4 & 0.7 & 5.7 \\
\hline Eurosid II & Dipterocarpaceae & Shorea platycarpa Heim. & tre & 17.2 & 0.8 & 5.1 \\
\hline Eurosid II & Dipterocarpaceae & Shorea ovalis (Korth.) Bl. & tre & 13.7 & 0.6 & 4.7 \\
\hline Eurosid II & Dipterocarpaceae & Shorea ovalis (Korth.) BI & tree & $1+0=$ & 0.7 & 4.9 \\
\hline Eurosid II & Dipterocarpaceae & Shorea teysm & tree & 10.5 & 09 & 5.5 \\
\hline Eurosid II & Dipterocarpaceae & Vatica $u$ & tree & 727 & 0.9 & 2.9 \\
\hline Eurosid II & Meliaceae & (Hiern) Pannel & tree & 22.7 & 1.1 & 7.7 \\
\hline $\begin{array}{l}\text { Eurosid II } \\
\text { Furoid II }\end{array}$ & $\begin{array}{l}\text { Meliaceae } \\
\text { Mytacaeae }\end{array}$ & $\begin{array}{l}\text { Agllaia odoratisssima B. } \\
\text { Myristic lowina King }\end{array}$ & tree & 19.9 & 2.1 & 7.4 \\
\hline $\begin{array}{l}\text { Eurosid II } \\
\text { Eurosid II }\end{array}$ & $\begin{array}{l}\text { Myytaceae } \\
\text { Myrtaceae }\end{array}$ & $\begin{array}{l}\text { Myristita lowinan King } \\
\text { Syyzgium havinandii Merr. }\end{array}$ & $\begin{array}{l}\text { tree } \\
\text { tree }\end{array}$ & 14.9 & 0.8 & 13.3 \\
\hline $\begin{array}{l}\text { Eurosid II } \\
\text { Eurosid II }\end{array}$ & $\begin{array}{l}\text { Myrtaceae } \\
\text { Myrtaceae }\end{array}$ & $\begin{array}{l}\text { SSyzgium havinnandin Merr. } \\
\text { Syyzgium grandis Wight }\end{array}$ & $\begin{array}{l}\text { tre } \\
\text { tre }\end{array}$ & ${ }_{113}^{17.6}$ & 0.9 & 8.1 \\
\hline Eurosid II & Myrtaceae & & & ${ }_{9.4}$ & 0.4 & $\begin{array}{l}4.1 \\
5.4\end{array}$ \\
\hline irosi & Rutaceae & $\begin{array}{l}\text { Syzygrum } 1 \text { Rosut ct. } \\
\text { Tetractomia cf. obovata Merr. }\end{array}$ & & 17.2 & 1.1 & 5.5 \\
\hline Eurosit & Sterculiaceae & tiera albiflora (Ridl.) Koste & tr & 14.6 & 0.5 & 4.2 \\
\hline 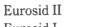 & Sterculiaceae & longiforam is & & 18.2 & 1.1 & 9.8 \\
\hline Eurosi & $\begin{array}{l}\text { Caesalpiniaceae } \\
\text { Clusiceae }\end{array}$ & $\begin{array}{l}\text { Koompassia malaccensis Maing. Ex. Benth. } \\
\text { Calofhhlymin inophylum King }\end{array}$ & tre & ${ }_{75}^{18.3}$ & 1.5 & 2.5 \\
\hline $\begin{array}{l}\text { Eurosid I } \\
\text { Eursoid I }\end{array}$ & $\begin{array}{l}\text { Clusicaeae } \\
\text { Clusiaceae }\end{array}$ & $\begin{array}{l}\text { Calophyllhm inoholyllum King } \\
\text { Clalopyllum sclerohyllum Vesque }\end{array}$ & trit & $\begin{array}{r}7.5 \\
11.1\end{array}$ & 0.2 & $\begin{array}{l}4.1 \\
5.9\end{array}$ \\
\hline $\begin{array}{l}\text { Eurosid I } \\
\text { Eurosid I }\end{array}$ & $\begin{array}{l}\text { Cluslaceae } \\
\text { Clusiaceae }\end{array}$ & $\begin{array}{l}\text { Iolhhllum sclerophyylum Vesque } \\
\text { lophyllum teysmannii Miq. }\end{array}$ & & 10 & 0.5 & $\begin{array}{l}.59 \\
6.2\end{array}$ \\
\hline $\begin{array}{l}\text { rossta I } \\
\text { rosid I }\end{array}$ & Clusiaceae & $u m$ Wall. & & 10.3 & 0.4 & 2.2 \\
\hline ros & Clusia & scens (Vahl.) Bl. & & 10. & 05 & 2.9 \\
\hline & Clusia & & & 13 & 0.5 & 7.1 \\
\hline Euros & Clusiac & & & & 0.3 & 3.5 \\
\hline & Clusiac & sterm. & $\operatorname{tr}$ & & 0.4 & 2.4 \\
\hline Euro: & Elaeocarpaceae & & & & 0.6 & 4.1 \\
\hline H & Elaeocarpaceae & $\lg$ & & 11 & 0.6 & 2.6 \\
\hline rosid I & $\begin{array}{l}\text { Euphorbiaceae } \\
\text { Fagacae }\end{array}$ & nuth & & & 0.6 & 9.7 \\
\hline rosid I & $\begin{array}{l}\text { Fagaceae } \\
\text { Fagaceae }\end{array}$ & $\begin{array}{l}\text { Vinkler } \\
\text { it. }\end{array}$ & & 14.7 & 0.6 & $\begin{array}{l}5.9 \\
3.8\end{array}$ \\
\hline $\begin{array}{l}\text { rosoid I } \\
\text { rosid I }\end{array}$ & 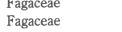 & & & 10.4 & 0.3 & $\begin{array}{l}3.8 \\
2.7\end{array}$ \\
\hline & 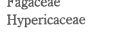 & 1.) & & $\begin{array}{l}8.4 \\
9.3\end{array}$ & $\begin{array}{l}0.5 \\
0.5\end{array}$ & $\begin{array}{l}2.7 \\
3.6\end{array}$ \\
\hline & $\begin{array}{l}\text { Hypenci } \\
\text { Moracea }\end{array}$ & maingayi Hook. & & $\begin{array}{l}9.3 \\
14.0\end{array}$ & 1.8 & 4.4 \\
\hline & $\begin{array}{l}\text { Morcices } \\
\text { Polygala }\end{array}$ & Xanthophyll & & 8 & 0.6 & 5.9 \\
\hline II & $\begin{array}{l}\text { Polygalata } \\
\text { Poysala }\end{array}$ & & & & 0.5 & \\
\hline iales & ceae & & & 17. & 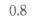 & \\
\hline ales & Laut & inw. Ex Blume & & 10 & 1. & 9.9 \\
\hline $\begin{array}{l}\text { rales } \\
\text { rales }\end{array}$ & La & (1) & & 10. & 0.3 & 4 \\
\hline ale & Lauraceae & 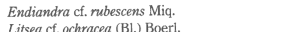 & & 10.7 & 0.8 & 6.3 \\
\hline $\begin{array}{l}\text { Laurales } \\
\text { Lats }\end{array}$ & Lauraceae & Litsea cf. ochracea (B.1.) Boerl. & tree & 10.7 & 0.5 & 3.9 \\
\hline
\end{tabular}




\begin{tabular}{|c|c|c|c|c|c|c|c|c|c|c|c|c|c|c|c|c|}
\hline $\begin{array}{l}\text { Phylogenetic } \\
\text { group" }\end{array}$ & Fan & Species & Form & $\mathrm{N}$ & $\mathbf{P}$ & $\begin{array}{c}\mathrm{K} \\
\left(\mathrm{g} \mathrm{kg}^{-1)}\right) \\
\end{array}$ & $\mathrm{Ca}$ & $\mathrm{Mg}_{\mathrm{g}}$ & $\mathrm{Na}$ & $\mathrm{Fe}$ & $\mathrm{Mn}$ & $\begin{array}{l}\mathrm{zn} \\
\mathrm{mggh}\end{array}$ & $\mathrm{Cu}$ & Mo & Al & $\mathrm{si}$ \\
\hline 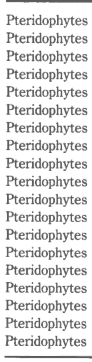 & 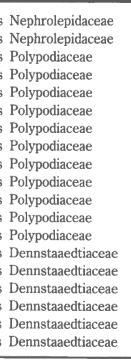 & 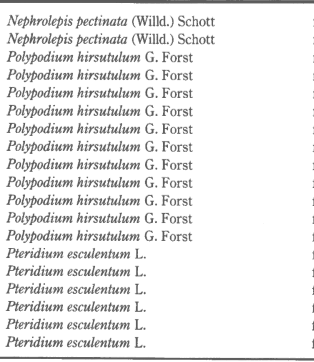 & 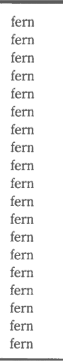 & $\begin{array}{l}15.9 \\
17.6 \\
4.1 \\
8.1 \\
8.1 \\
8.5 \\
8.6 \\
8.7 \\
8.7 \\
8.8 \\
9.5 \\
10.7 \\
6.2 \\
7.5 \\
8.3 \\
9.7 \\
16.0 \\
16.0\end{array}$ & $\begin{array}{l}0.8 \\
0.4 \\
0.2 \\
0.3 \\
0.3 \\
0.5 \\
0.4 \\
0.4 \\
0.7 \\
0.3 \\
0.4 \\
0.5 \\
0.3 \\
0.3 \\
0.8 \\
0.8 \\
0.9 \\
1.5 \\
\end{array}$ & $\begin{array}{l}14.4 \\
1.4 \\
11.9 \\
1.84 \\
11.8 \\
1.8 \\
19.5 \\
19.9 \\
1.6 .6 \\
11.7 \\
11.8 \\
11.7 \\
13.3 \\
11.2 \\
11.8 \\
11.8 \\
11.9 \\
12.5\end{array}$ & $\begin{array}{l}6.1 \\
14.2 \\
7.0 \\
4.9 \\
3.4 \\
5.5 \\
7.1 \\
5.1 \\
5.1 \\
6.9 \\
6.3 \\
.3 .3 \\
5.0 \\
0.7 \\
2.0 \\
.7 .9 \\
7.9 \\
4.9 \\
4.3 \\
\end{array}$ & $\begin{array}{l}3.5 \\
9.6 \\
5.3 \\
3.9 \\
3.9 \\
3.5 \\
5.0 \\
4.0 \\
4.0 \\
4.5 \\
5.1 \\
6.3 \\
6.3 \\
0.4 \\
1.9 \\
1.9 \\
7.5 \\
1.5 \\
3.4 \\
3.6\end{array}$ & $\begin{array}{l}639 \\
579 \\
413 \\
113 \\
368 \\
740 \\
5501 \\
543 \\
567 \\
203 \\
223 \\
634 \\
379 \\
502 \\
721 \\
385 \\
141 \\
845 \\
70 \\
\end{array}$ & $\begin{array}{l}41 \\
19 \\
46 \\
17 \\
42 \\
21 \\
31 \\
23 \\
69 \\
50 \\
52 \\
33 \\
30 \\
21 \\
20 \\
6 \\
46 \\
6 \\
39 \\
\end{array}$ & $\begin{array}{l}282 \\
195 \\
55 \\
48 \\
48 \\
224 \\
148 \\
79 \\
302 \\
181 \\
175 \\
283 \\
106 \\
22 \\
16 \\
98 \\
198 \\
98 \\
67 \\
67\end{array}$ & $\begin{array}{l}0.4 \\
7.0 \\
5.8 \\
2.8 .8 \\
4.0 \\
5.3 \\
51.1 \\
11.1 \\
11.2 \\
4.9 \\
16.0 \\
11.0 \\
19.9 \\
3.3 \\
7.5 \\
9.0 \\
8.8 \\
15.0 \\
34.3\end{array}$ & $\begin{array}{l}0.5 \\
6.2 \\
4.7 \\
8.6 \\
1.4 \\
3.3 \\
2.0 \\
0.9 \\
0.7 \\
0.7 \\
6.2 \\
2.4 \\
2.8 \\
7.5 \\
1.1 \\
1.8 \\
.8 .8 \\
3.7 \\
3.7\end{array}$ & $\begin{array}{l}12.4 \\
12.2 \\
15.7 \\
12.2 \\
13.2 \\
10.3 \\
16.5 \\
16.3 \\
12.3 \\
17.8 \\
11.7 \\
11.6 \\
14.8 \\
16.4 \\
18.3 \\
11.1 \\
13.9 \\
8.7 \\
10.2 \\
\end{array}$ & $\begin{array}{l}15 \\
19 \\
170 \\
142 \\
65 \\
90 \\
80 \\
60 \\
68 \\
87 \\
57 \\
3 \\
66 \\
1 \\
28 \\
5 \\
42 \\
4 \\
17\end{array}$ & $\begin{array}{c}208 \\
6 \\
19 \\
74 \\
60 \\
32 \\
55 \\
44 \\
45 \\
32 \\
61 \\
41 \\
43 \\
63 \\
31 \\
20 \\
33 \\
10 \\
149\end{array}$ \\
\hline & & & & & & & & & mp fores & shallo & peat (K & alampat & & & & \\
\hline 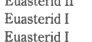 & $\begin{array}{l}\text { Aposynaceae } \\
\text { Aper }\end{array}$ & 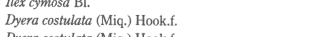 & $\begin{array}{l}\text { tree } \\
\text { tree }\end{array}$ & & & & $\begin{array}{l}4.7 \\
2.8\end{array}$ & 1.0 & ${ }_{93}^{126}$ & $\begin{array}{r}6 \\
35\end{array}$ & 14 & $\begin{array}{r}4.7 \\
104\end{array}$ & $\begin{array}{l}5.1 \\
4.7\end{array}$ & & & \\
\hline 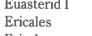 & $\begin{array}{l}\text { Apcoynaceae } \\
\text { Ebenaceae }\end{array}$ & 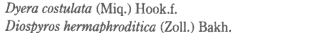 & $\begin{array}{c}\text { tree } \\
\text { tree }\end{array}$ & 1.1 & 0.5 & 7.9 & $\begin{array}{l}2.0 \\
9.1 \\
91\end{array}$ & 2. & $\begin{array}{l}93 \\
42\end{array}$ & $\begin{array}{l}35 \\
53\end{array}$ & $\begin{array}{l}186 \\
209\end{array}$ & & $\begin{array}{l}4.7 \\
2.2\end{array}$ & $\begin{array}{l}\begin{array}{l}14.8 \\
10.1\end{array}\end{array}$ & $\begin{array}{l}20 \\
13\end{array}$ & \\
\hline & 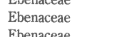 & 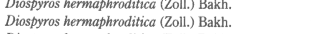 & tree & 3.7 & ${ }_{0.2}^{0.4}$ & $\begin{array}{l}17.5 \\
15.8\end{array}$ & $\begin{array}{l}8.1 \\
3.9\end{array}$ & $\begin{array}{l}6.0 \\
35\end{array}$ & $\begin{array}{l}166 \\
78\end{array}$ & 81 & $\begin{array}{l}1112 \\
4145 \\
485\end{array}$ & 3.9 & 5.4 & 14.4 & & ${ }_{41}^{7}$ \\
\hline les & $\begin{array}{l}\text { Ebenaceae } \\
\text { Ebenaceae }\end{array}$ & & $t$ & 1 & 0.5 & $\begin{array}{l}10.8 \\
10.7\end{array}$ & $\begin{array}{l}3.9 \\
5.6\end{array}$ & $\begin{array}{l}3.5 \\
3.4\end{array}$ & $\begin{array}{l}18 \\
92\end{array}$ & $\begin{array}{l}16 \\
92\end{array}$ & $\begin{array}{l}480 \\
857\end{array}$ & $\begin{array}{l}4.4 \\
3.9\end{array}$ & $\begin{array}{l}.03 \\
2.8\end{array}$ & $\begin{array}{l}16.6 \\
14.5\end{array}$ & & $\begin{array}{l}28 \\
28 \\
20\end{array}$ \\
\hline 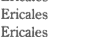 & $\begin{array}{l}\text { Ebenceae } \\
\text { Ebencea } \\
\text { Ehbencea }\end{array}$ & $\begin{array}{l}\text { Diossyyos hermaphroditica (Zoll.) Bat } \\
\text { Disssyros hermashroditica (Zoll.) Bat }\end{array}$ & $e$ & .7 & 0.2 & 10.2 & ${ }^{6.8}$ & 4.2 & ${ }^{151}$ & 35 & 347 & 3.6 & 0.4 & 9.3 & & \\
\hline $\begin{array}{l}\text { cales } \\
\text { cales }\end{array}$ & $\begin{array}{l}\text { Ebbanceae } \\
\text { Ebenaceae }\end{array}$ & 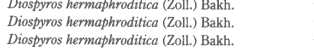 & tree & 6 & ${ }_{0.1}^{0.2}$ & $\begin{array}{l}16.0 \\
9.8\end{array}$ & $\begin{array}{l}4.3 \\
2.5\end{array}$ & $\begin{array}{l}3.5 \\
1.2\end{array}$ & $\begin{array}{r}34 \\
309\end{array}$ & $\begin{array}{l}35 \\
20\end{array}$ & $\begin{array}{l}787 \\
141\end{array}$ & $\begin{array}{r}4.2 \\
15.4\end{array}$ & $\begin{array}{l}5.8 \\
2.8\end{array}$ & $\begin{aligned} & 17.0 \\
& 5.2\end{aligned}$ & $\begin{array}{c}3 \\
50\end{array}$ & $\begin{array}{r}9 \\
34\end{array}$ \\
\hline cales & 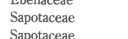 & 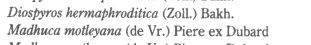 & $\begin{array}{c}\text { tree } \\
\text { tree }\end{array}$ & 12.7 & 0.2 & $\begin{array}{c}18.2 \\
5.2\end{array}$ & 3.9 & 2.4 & $\begin{array}{l}2091 \\
251\end{array}$ & 22 & $\begin{array}{l}741 \\
409\end{array}$ & $\begin{array}{l}11.8 \\
11.8\end{array}$ & 0.2 & $\begin{array}{l}5.2 \\
7.5\end{array}$ & $\begin{array}{l}50 \\
17\end{array}$ & \\
\hline vales & $\begin{array}{l}\text { Sapotaceae } \\
\text { Tetrameristac }\end{array}$ & 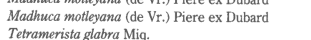 & tree & 吕.5 & $\begin{array}{l}0.4 \\
0.5\end{array}$ & $\begin{array}{l}5.9 \\
5.4\end{array}$ & $\begin{array}{l}6.8 \\
6.5\end{array}$ & $\begin{array}{l}3.1 \\
3.3\end{array}$ & $\begin{array}{l}58 \\
114\end{array}$ & 尊9 & 19 & 4.8 & 3.3 & 13.7 & 63 & $\begin{array}{c}3 \\
104^{3}-x-3\end{array}$ \\
\hline $\begin{array}{ll}\text { cales } \\
\text { cales } \\
\text { cales }\end{array}$ & Tetrameristace & 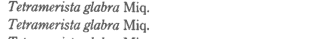 & $\begin{array}{l}\text { tree } \\
\text { tree }\end{array}$ & $\begin{array}{l}7.5 \\
9.5 \\
\end{array}$ & 0.1 & 11.1 & 4.2 & 2.5 & 181 & 10 & 12 & 5.3 & 6.7 & $\begin{array}{l}13.2 \\
13.2\end{array}$ & $\begin{array}{l}8 \\
2\end{array}$ & ${ }_{3}^{107}$ \\
\hline ales & $\begin{array}{l}\text { Tetrameristaceae } \\
\text { Tetrameristaceae }\end{array}$ & $\begin{array}{l}\text { Tetramenistat } \\
\text { Tetramertat }\end{array}$ & 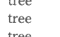 & 1 & & $\begin{array}{l}9.1 \\
9.6\end{array}$ & $\begin{array}{l}3.8 \\
5.7\end{array}$ & $\begin{array}{l}0.9 \\
2.7\end{array}$ & ${ }_{34}^{4}$ & ${ }_{67}^{14}$ & ${ }_{6}^{12}$ & $\begin{array}{l}4.8 \\
3.9\end{array}$ & $\begin{array}{l}3.8 \\
140\end{array}$ & $\begin{array}{l}12.5 \\
14.1\end{array}$ & $\begin{array}{l}6 \\
7\end{array}$ & $\begin{array}{c}3 \\
33 \\
3\end{array}$ \\
\hline ates & $\begin{array}{l}\text { rameristaceae } \\
\text { ramerscape }\end{array}$ & $\begin{array}{l}\text { Tetrameristst glabra Miq. } \\
\text { Tetramerista glabra Miq. }\end{array}$ & tre & & 0.2 & 9.9 & 2.3 & 0.5 & 392 & 11 & 19 & $\begin{array}{l}3.9 \\
15.7\end{array}$ & 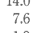 & $\begin{array}{r}14.1 \\
5.6\end{array}$ & 54 & ${ }^{74}$ \\
\hline $\begin{array}{l}\text { ales } \\
\text { ales }\end{array}$ & $\begin{array}{l}\text { rameristaceae } \\
\text { rameristaceae }\end{array}$ & $\begin{array}{l}\text { Tetrameristat } \\
\text { Tetramerits }\end{array}$ & $\begin{array}{l}\text { tree } \\
\text { tree }\end{array}$ & & $\begin{array}{l}.1 \\
0.1\end{array}$ & $\begin{array}{l}10.0 \\
8.4\end{array}$ & $\begin{array}{l}1.9 \\
2.1\end{array}$ & $\begin{array}{l}0.5 \\
1.0\end{array}$ & $\begin{array}{l}3335 \\
375\end{array}$ & $\begin{array}{l}10 \\
12\end{array}$ & $\begin{array}{r}25 \\
6\end{array}$ & $\begin{array}{l}{ }_{2}^{14.4} \\
2.7\end{array}$ & $\begin{array}{l}1.3 \\
1.9\end{array}$ & $\begin{array}{l}3.0 \\
9.9\end{array}$ & ${ }_{11}^{12}$ & $8_{3}^{8}$ \\
\hline tosid II & Dipterocarpaceae & $\begin{array}{l}\text { Tetramernst } \\
\text { Shorea bala }\end{array}$ & $\begin{array}{l}\text { 䗆e } \\
\text { tree }\end{array}$ & & $\begin{array}{l}0.2 \\
0.3\end{array}$ & $\begin{array}{l}11.5 \\
6.7\end{array}$ & 7.3 & 2.3 & $\begin{array}{l}210 \\
150\end{array}$ & 11 & & 3.1 & 1.3 & 6.7 & 35 & $\frac{3}{4}$ \\
\hline 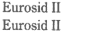 & $\begin{array}{l}\text { Dipterocarpaceae } \\
\text { Dipterocarpaceae }\end{array}$ & rth.) Burck & 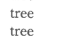 & & 0.6 & 5.8 & 8.4 & $\begin{array}{l}2.1 \\
1.1\end{array}$ & 84 & $\begin{array}{l}19 \\
129\end{array}$ & 608 & $\begin{array}{l}3.7 \\
4.0\end{array}$ & $\begin{array}{l}1.2 \\
5.8\end{array}$ & $\begin{array}{l}13.9 \\
12.8\end{array}$ & & ${ }_{25}^{32}$ \\
\hline $\begin{array}{l}\text { osid II } \\
\text { osid }\end{array}$ & $\begin{array}{l}\text { Dipterocappaceae } \\
\text { Dipterocarpaceae }\end{array}$ & $\begin{array}{l}\text { Shorea latat } \\
\text { Shorea plat }\end{array}$ & & & ${ }_{0.3}^{0.3}$ & $\begin{array}{l}2.4 \\
5.0\end{array}$ & 1.8 & 1.5 & 6 & 19 & 170 & 13.1 & 4.0 & 14.9 & 7 & \\
\hline $\begin{array}{llll}\text { osid II } \\
\text { sidi II }\end{array}$ & $\begin{array}{l}\text { Dipterocarpaceae } \\
\text { Melastomatatacear }\end{array}$ & 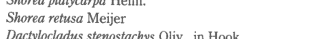 & tre & & ${ }_{0.3}^{.03}$ & 6.3 & $\begin{array}{l}4.8 \\
4.2\end{array}$ & $\begin{array}{l}0.8 \\
1.4\end{array}$ & $\begin{array}{l}3817 \\
289\end{array}$ & ${ }_{25}^{16}$ & $\begin{array}{l}23 \\
94\end{array}$ & $\begin{array}{l}10.4 \\
2.8\end{array}$ & ${ }_{22}^{0.2}$ & $\begin{array}{r}4.3 \\
15.1\end{array}$ & ${ }^{21}$ & 11 \\
\hline $\begin{array}{l}\text { rossid } \\
\text { rosid II }\end{array}$ & Myrtaceae & 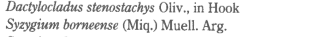 & $\begin{array}{c}\text { the } \\
\text { tre }\end{array}$ & & 0.3 & $\begin{array}{l}6.3 \\
79\end{array}$ & 4.9 & 2.9 & 110 & 15 & 17 & 5.0 & 0.5 & 15.1 & $\begin{array}{l}14 \\
12\end{array}$ & 18 \\
\hline $\begin{array}{l}\text { osid II } \\
\text { sid II }\end{array}$ & $\begin{array}{l}\text { Mytraceae } \\
\text { Myytaceae }\end{array}$ & Syzygrium bormeense (Miq,) Muell. & tree & & $\begin{array}{l}0.2 \\
0.1\end{array}$ & $\begin{array}{r}7.9 \\
11.1\end{array}$ & $\begin{array}{l}10.4 \\
100\end{array}$ & ${ }_{13}^{2.4}$ & ${ }_{226}^{122}$ & $\begin{array}{l}56 \\
17\end{array}$ & 9 & $\begin{array}{r}4.3 \\
139\end{array}$ & 8.4 & $\begin{array}{l}15.2 \\
{ }_{18}\end{array}$ & 10 & $\begin{array}{r}8 \\
22\end{array}$ \\
\hline id II & $\begin{array}{l}\text { Myrtacee } \\
\text { Myrtaceae }\end{array}$ & 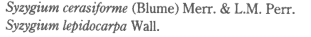 & $\begin{array}{l}\text { tree } \\
\text { tree }\end{array}$ & & 0.2 & 2.6 & 5.3 & ${ }_{1.1}^{1.0}$ & $26 \mathrm{E}$ & & ${ }_{441}^{21}$ & $\begin{array}{r}13.9 \\
6.2\end{array}$ & $\begin{array}{l}4.6 \\
6.4\end{array}$ & $\begin{array}{r}4.8 \\
12.8\end{array}$ & $\begin{array}{l}66 \\
49\end{array}$ & 14 \\
\hline id II II & $\begin{array}{l}\text { Mytraceae } \\
\text { Myltaceae }\end{array}$ & 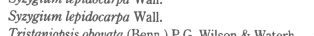 & $\begin{array}{l}\text { the } \\
\text { tree }\end{array}$ & 10.5 & ${ }_{0.2}^{0.2}$ & $\begin{array}{l}3.4 \\
14.7\end{array}$ & $\begin{array}{l}7.5 \\
6.8\end{array}$ & 0.8 & 214 & 13 & 18 & 4.1 & 8.2 & 11.0 & & ${ }_{81}^{16}$ \\
\hline id II & $\begin{array}{l}\text { Syltaceae } \\
\text { Rutaceae }\end{array}$ & 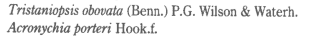 & tree & 8.6 & 0.2 & 7.1 & 10.7 & 年.9. & ${ }_{23}$ & 15 & $\begin{array}{l}30 \\
42\end{array}$ & $\begin{array}{l}5.6 \\
3.1\end{array}$ & 0.3 & $\begin{array}{l}11.4 \\
13.9\end{array}$ & ${ }_{12}^{66}$ & 15 \\
\hline $\begin{array}{l}\text { sidil } \\
\text { sidi } \\
\text { sid }\end{array}$ & $\begin{array}{l}\text { culiaceae } \\
\text { melaeacere }\end{array}$ & 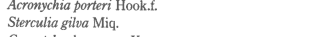 & 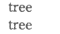 & & 0.2 & $\begin{array}{l}3.8 \\
8.0\end{array}$ & $\begin{array}{c}6.0 \\
5.9\end{array}$ & 1.0 & ${ }_{524}^{141}$ & ${ }_{28}^{23}$ & 7 & 4.4 & 1.5 & 11.6 & 90 & 124 \\
\hline sid II & 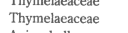 & 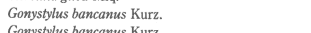 & $\begin{array}{l}\text { tree } \\
\text { tres }\end{array}$ & 0 & o.1. & 8.0 & & 0.6 & $\begin{aligned} 324 \\
338\end{aligned}$ & 28 & 海3 & $\begin{array}{l}12.4 \\
58\end{array}$ & $\begin{array}{l}1.0 \\
38\end{array}$ & $\begin{array}{l}4.3 \\
57\end{array}$ & 29 & 2 \\
\hline sid I I & & 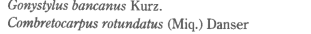 & $\begin{array}{l}\text { tree } \\
\text { tree }\end{array}$ & & 0.3 & 2.6 & 5.6 & 1.5 & 416 & 100 & 257 & 0.4 & 1.1 & 11.9 & $\stackrel{21}{5}$ & 10 \\
\hline & & 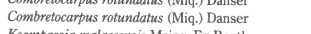 & $\begin{array}{l}\text { tree } \\
\text { tre. }\end{array}$ & & $0^{3}$ & $\begin{array}{l}8.5 \\
6.5\end{array}$ & 3.5 & 1.9 & 161 & 40 & 432 & 12.3 & 4.5 & 14.6 & 8294 & 28 \\
\hline Eurositi & $\begin{array}{l}\text { Casasplinicaea } \\
\text { Caesalpininceae }\end{array}$ & ssia malacec & tree & & 0.3 & 2.8 & $\begin{array}{l}4.0 \\
6.6\end{array}$ & 2.6 & ${ }_{72}^{109}$ & 19 & 3 & $\begin{array}{l}3.8 \\
5.2\end{array}$ & 3.7 & $\begin{array}{l}14.7 \\
13.8\end{array}$ & 8578 & 13 \\
\hline Eurosid I & 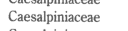 & Koompassisia & tre & $\begin{array}{l}14.2 \\
1.7 .0\end{array}$ & 0.6 & 3.2 & 5.9 & 2.9 & 42 & 37 & 15 & 4.9 & 70 & $\begin{array}{l}15.6 \\
15.4\end{array}$ & & \\
\hline $\begin{array}{l}\text { Eurosid I } \\
\text { Eurosid }\end{array}$ & $\begin{array}{l}\text { Caesalpininceae } \\
\text { Celastraceae }\end{array}$ & nsis Maing. Ex Benth. & $\begin{array}{c}\text { tree } \\
\text { tree }\end{array}$ & $\begin{array}{l}13.1 .1 \\
13.2\end{array}$ & 0.2 & $\begin{array}{l}9.0 \\
3.0\end{array}$ & $\begin{array}{l}3.9 \\
6.8\end{array}$ & 2.9 & $\begin{array}{l}62 \\
366\end{array}$ & ${ }_{11}^{44}$ & $\begin{array}{l}28 \\
132\end{array}$ & $\begin{array}{r}3.7 \\
16.6\end{array}$ & $\begin{array}{l}4.2 \\
2.0\end{array}$ & $\begin{array}{l}12.1 \\
5.0\end{array}$ & $\begin{array}{r}8 \\
30\end{array}$ & ${ }_{35}^{41}$ \\
\hline 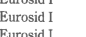 & $\begin{array}{l}\text { Clusiaceae } \\
\text { Cluizer }\end{array}$ & 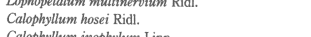 & $\begin{array}{l}\text { tree } \\
\text { tree }\end{array}$ & $\begin{array}{c}12.3 \\
6.6\end{array}$ & 0.1 & $\begin{array}{r}5.9 \\
10.7\end{array}$ & $\begin{array}{l}5.8 \\
26\end{array}$ & 1.4 & ${ }_{29}^{435}$ & 17 & 26 & 7.3 & 0.6 & 5.3 & & 20 \\
\hline sid I & Clusiaceae & 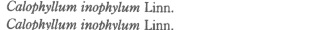 & tre & 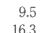 & 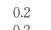 & 6.2 & 10.6 & 2.7 & 122 & 28 & $\begin{array}{r}2 \\
28\end{array}$ & $\begin{array}{l}4.4 \\
4.1\end{array}$ & $\begin{array}{l}0.3 \\
3.8\end{array}$ & $\begin{array}{l}12.4 \\
11.7\end{array}$ & & ${ }_{13}^{45}$ \\
\hline - & Clysicuar & Calophyllum it & & $\begin{array}{c}16.3 \\
9.3 \\
-3\end{array}$ & 0.2 & $\begin{array}{l}7.5 \\
8.6\end{array}$ & $\begin{array}{l}7.1 \\
62\end{array}$ & 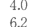 & ${ }_{36}^{72}$ & ${ }_{48}^{39}$ & 361 & 10.8 & 1.4 & 14.2 & & \\
\hline $\begin{array}{l}\text { isd } \\
\text { idI } \\
\text { f }\end{array}$ & $\begin{array}{l}\text { Clusiaceae } \\
\text { Clusisceae }\end{array}$ & 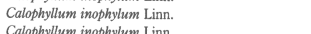 & tre & $\begin{array}{l}16.7 \\
16.7 \\
\end{array}$ & 0.6 & $\begin{array}{l}0.0 \\
10.8\end{array}$ & $\begin{array}{l}0.4 \\
4.4\end{array}$ & $\begin{array}{l}0.2 \\
5.2\end{array}$ & & $\begin{array}{l}48 \\
95\end{array}$ & $\begin{array}{l}17 \\
431\end{array}$ & $\begin{array}{l}4.5 \\
4.3\end{array}$ & $\begin{array}{l}10.4 \\
12.5\end{array}$ & $\begin{array}{l}13.5 \\
15.9\end{array}$ & & ${ }_{124}^{24}$ \\
\hline sosid I & 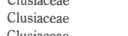 & $\begin{array}{l}2 \text { Linn. } \\
\text { Linn. }\end{array}$ & tre & $\begin{array}{r}7.9 \\
12.4 \\
\end{array}$ & & $\begin{array}{l}5.4 \\
59\end{array}$ & 3.0 & 0.7 & $\begin{array}{l}296 \\
329\end{array}$ & 15 & 24 & 9.4 & 4.4 & & & 5 \\
\hline & $\begin{array}{l}\text { Cllsicacae } \\
\text { Clusiceae }\end{array}$ & & & 6 & & 1.8 & 5.0 & $\begin{array}{l}.0 .2 \\
1.2\end{array}$ & 189 & ${ }_{37}^{15}$ & $\begin{array}{l}35 \\
284\end{array}$ & $\begin{array}{l}8.9 \\
3.3\end{array}$ & $\begin{array}{l}4.0 \\
6.2\end{array}$ & $\begin{array}{r}5.3 \\
13.6\end{array}$ & & 7 \\
\hline silat & $\begin{array}{l}\text { Cusscace } \\
\text { Clusiceae }\end{array}$ & f. & $\begin{array}{l}\text { trey } \\
\text { tree } \\
\text {. }\end{array}$ & 6.3 & & $\begin{array}{r}4.0 \\
138\end{array}$ & $\begin{array}{l}4.3 \\
5.3\end{array}$ & ${ }_{57}^{2.6}$ & ${ }_{254}^{151}$ & ${ }_{20}^{26}$ & 12 & 4.3 & 2.9 & $\begin{array}{l}12.3 .3 \\
12.3 \\
\end{array}$ & 6 & 40 \\
\hline 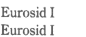 & $\begin{array}{l}\text { ceae } \\
\text { ceaze } \\
\text { col }\end{array}$ & tit. & tre & 14.5 & & $\begin{array}{l}13.8 \\
13.4\end{array}$ & 4.4. & $\begin{array}{l}5.7 \\
2.9\end{array}$ & $\begin{array}{l}254 \\
368\end{array}$ & ${ }_{27}^{22}$ & & $\begin{array}{l}5.0 \\
5.7\end{array}$ & $\begin{array}{l}0.4 \\
3.7\end{array}$ & $\begin{array}{l}5.4 \\
4.8\end{array}$ & $\begin{array}{l}88 \\
26\end{array}$ & 14 \\
\hline sidt & 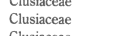 & k. . & $\begin{array}{l}\text { tre } \\
\text { tre }\end{array}$ & $\begin{array}{l}19.3 \\
17.2 \\
\mathrm{C} C \mathrm{C}\end{array}$ & & 10.4 & $\begin{array}{l}3.4 \\
5.7\end{array}$ & $\begin{array}{l}2.0 \\
2.8\end{array}$ & 379 & 21 & 250 & & & & & 3 \\
\hline & $\begin{array}{l}\text { Clusiacae } \\
\text { Clusiceae }\end{array}$ & $\begin{array}{l}\text { fyllum } \\
\text { ind dio }\end{array}$ & tree & 5.7 .7 & 2 & $\begin{array}{l}11.0 \\
11.0\end{array}$ & $\begin{array}{l}5.9 \\
5.9\end{array}$ & $\begin{array}{l}2.8 \\
1.6\end{array}$ & 219 & $\begin{array}{l}21 \\
40\end{array}$ & 36 & $\begin{array}{l}8.5 \\
5.4\end{array}$ & & 5.0 & & 2 \\
\hline & de & 等 & tre & 7.9 & 0.1 & 7.7 & ${ }^{5.6}$ & 1.9 & $\begin{array}{l}468 \\
201 \\
201\end{array}$ & 19 & 31 & 15.8 & 0.9 & 6.2 & & 17 \\
\hline sid I I & & ppsist & tre & 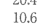 & 0.2 & $\begin{array}{l}16.2 \\
7.4\end{array}$ & $\begin{array}{l}1.2 .2 \\
9.9\end{array}$ & $\begin{array}{l}{ }_{1.1}^{1} \\
19\end{array}$ & $\begin{array}{ll}321 \\
4\end{array}$ & $\begin{array}{l}19 \\
56\end{array}$ & 43 & 19.5 & 00 & 5.3 & 54 & 17 \\
\hline & & & $\operatorname{tr}$ & & & 8.0 & 8.6 & 2. & $\begin{array}{l}125 \\
028\end{array}$ & $\begin{array}{l}50 \\
66\end{array}$ & $\begin{array}{l}36 \\
11\end{array}$ & $\begin{array}{l}4.0 \\
9.4 \\
9.4\end{array}$ & $\begin{array}{l}3.5 \\
7.4\end{array}$ & $\begin{array}{c}16.2 \\
9.3\end{array}$ & $\begin{array}{r}4 \\
10\end{array}$ & 165 \\
\hline trales & $\begin{array}{l}\text { Annonaceae } \\
\text { Lauraceae }\end{array}$ & oumum sintoc B.]. & tree & & & $\begin{array}{r}5.9 \\
11.8\end{array}$ & 2.2 & & 560 & 63 & 293 & $\begin{array}{l}3.7 \\
0.4\end{array}$ & $\begin{array}{l}0.5 \\
3.0\end{array}$ & $\begin{array}{l}12.8 \\
11.2\end{array}$ & $\begin{array}{c}6 \\
38\end{array}$ & 11 \\
\hline & & & & & & & & & & & & & & & & \\
\hline & $\begin{array}{l}\text { Sapotcaza } \\
\text { Annacardia }\end{array}$ & P. van Roy & $\begin{array}{l}\text { tree } \\
\text { tree }\end{array}$ & & & $\begin{array}{l}4.0 \\
5.8\end{array}$ & & & & 16 & 48 & & & & & \\
\hline & Anz & & & & & & & & & & & & & & & \\
\hline & An & ${ }^{c}$ & tre & & & 4.8 & & & & & & & & & & \\
\hline & $\begin{array}{l}\text { yyle } \\
\text { y.te }\end{array}$ & $c_{a}$ & tre & & & 9 & & & & & 9 & 6.8 & 9.2 & & & 3 \\
\hline & & & & & & 7. & & & $\begin{array}{l}75 \\
32\end{array}$ & & 163 & 6.5 & 3.4 & .6 & 5 & ${ }_{10}^{12}$ \\
\hline & & $\begin{array}{l}\text { Daniser } \\
\text { Danser }\end{array}$ & & & & $\begin{array}{c}7.7 \\
10.2\end{array}$ & 5.1 & & & & & & 1.1 & 7.0 & & \\
\hline & & Danser & & & & 6.8 & 5.4 & & & & & & i. & 7.0 & & $\begin{array}{c}3 \\
12\end{array}$ \\
\hline & & $\begin{array}{l}D i t \\
L y_{y}\end{array}$ & & & 0. & $\begin{array}{l}{ }_{3.1}^{12.7} \\
3.1\end{array}$ & $\begin{array}{l}2.2 \\
1.6 \\
\end{array}$ & & & 553 & 235 & $\begin{array}{r}8 \\
13 \\
13\end{array}$ & ${ }_{0}^{4}$ & 10 & & 54 \\
\hline & & ild) Schott & & & & 15.2 & $172^{2}$ & & & 84 & 369 & 25.2 .2 & & & 30 & 4 \\
\hline & & & & & & $\begin{array}{l}10.7 \\
13.5\end{array}$ & & & & & & & & & & 564 \\
\hline & & & & & & 10.3. & 4.1. & & & 19 & & & & & 26 & \\
\hline & & st & fe & & 0 & $\begin{array}{l}1.3 .3 \\
9.3\end{array}$ & $\begin{array}{l}0.0 \\
3.8\end{array}$ & 2. & & 57 & $\begin{array}{l}1770 \\
47\end{array}$ & $\begin{array}{l}10.6 \\
2.7\end{array}$ & & & 43 & $\begin{array}{l}4 \\
1\end{array}$ \\
\hline dophyy & & 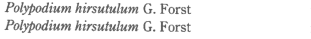 & fern & 11.1 & 0.4 & 6.0 & & & & 1 & 78 & & 3 & ${ }_{94}$ & 71 & 3 \\
\hline
\end{tabular}




\begin{tabular}{|c|c|c|c|c|c|c|c|c|c|c|c|c|c|c|c|c|}
\hline $\begin{array}{l}\begin{array}{l}\text { Phylogenetic } \\
\text { group* }\end{array} \\
\end{array}$ & \multirow{2}{*}{ Family } & \multirow{2}{*}{ Species } & \multirow{2}{*}{ Form } & $\mathrm{N}$ & $\mathbf{P}$ & $\mathbf{K}$ & $\mathrm{Ca}$ & $\underline{\mathrm{Mg}}$ & $\mathrm{Na}$ & $\mathrm{Fe}$ & Mn & $\mathrm{Zn}$ & $\mathrm{Cu}$ & Mo & Al & $\mathrm{Si}$ \\
\hline & & & & \multicolumn{5}{|c|}{$\begin{array}{cc}P & \mathrm{~K} \\
& \left(\mathrm{~g} \mathrm{~kg}^{-1}\right) \\
\end{array}$} & \multicolumn{8}{|c|}{$\left(\mathrm{mg} \mathrm{kg}^{-1}\right)$} \\
\hline $\begin{array}{l}\text { Pencopopytes } \\
\text { Pteridophytes }\end{array}$ & $\begin{array}{l}\text { Polypodiaceae } \\
\text { Polypodiaceae }\end{array}$ & $\begin{array}{l}\text { Polypodium hirsutulum G. Forst } \\
\text { Polypodium hirsutulum G. Forst }\end{array}$ & ferm & $\begin{array}{l}11.3 \\
120\end{array}$ & 0.6 & 12.1 & 5.5 & 4.5 & $\begin{array}{l}379 \\
558\end{array}$ & 53 & 161 & 8.0 & 3.3 & $\begin{array}{l}12.4 \\
10.7\end{array}$ & 37 & 24 \\
\hline Pteridophytes & Polypodiaceae & Polypodium hirsutulum G. Forst & $\begin{array}{l}\text { Tern } \\
\text { fern }\end{array}$ & 12.6 & $\begin{array}{l}0.3 \\
0.3\end{array}$ & $\begin{array}{l}12.3 \\
11.8\end{array}$ & $\begin{array}{l}4.0 \\
5.3\end{array}$ & $\begin{array}{l}2.2 \\
3.2\end{array}$ & $\begin{array}{l}578 \\
411\end{array}$ & $\begin{array}{l}14 \\
24\end{array}$ & $\begin{array}{l}51 \\
59\end{array}$ & $\begin{array}{l}3.1 \\
2.8\end{array}$ & $\begin{array}{l}2.3 \\
1.4\end{array}$ & $\begin{array}{l}10.7 \\
10.6\end{array}$ & $\begin{array}{l}36 \\
96\end{array}$ & $\begin{array}{l}3 \\
8\end{array}$ \\
\hline Pteridophytes & Polypodiaceae & Polyppodium hirsutulum G. Forst & fern & 12.9 & 0.8 & $\begin{array}{l}1.6 \\
13.9\end{array}$ & 2.1 & 3.1 & 395 & ${ }_{34}^{64}$ & 38 & 2.1 & 5.7 & 9.2 & 27 & $\begin{array}{l}8 \\
5\end{array}$ \\
\hline Pteridophytes & Polypodiaceae & Polypodium hit & fern & 13.1 & 0.8 & 12.4 & 1.9 & 1.9 & 378 & 131 & 41 & 5.5 & 8.9 & 10.8 & 175 & 78 \\
\hline Pteridophytes & Polypodiaceae & $\begin{array}{l}\text { Polypodium hirsutulum G.I } \\
\text { Pteridium mesulentum L } \mathrm{L}\end{array}$ & fern & 13.9 & 0.7 & 11.0 & 1.1 & 1.3 & 294 & 49 & 14 & 7.1 & 4.1 & 8.7 & 194 & 19 \\
\hline Pteridophytes & $\begin{array}{l}\text { Sennstaazedtiaceae } \\
\text { Dennstazaedticaeae }\end{array}$ & & $\begin{array}{l}\text { fern } \\
\text { fern }\end{array}$ & 11.4 & 0.2 & 8.0 & 3.7 & 0.8 & 522 & 12 & 108 & 6.7 & 2.1 & $\begin{array}{r}10.6 \\
9.0\end{array}$ & $\begin{array}{l}37 \\
78\end{array}$ & 10 \\
\hline $\begin{array}{l}\text { Pteridophytes } \\
\text { Pteridionbtes }\end{array}$ & $\begin{array}{l}\text { Dennstsaaedticacee } \\
\text { s Dennstaaedtiaceae }\end{array}$ & $\begin{array}{l}\text { PPerdidium sesculentum } \mathrm{L} \text {. } \\
\text { Pteridium esculentum } \mathrm{L} \text {. }\end{array}$ & $\begin{array}{l}\text { ferm } \\
\text { fern }\end{array}$ & 12.1 & 0.9 & 12.0 & 2.2 & 2.6 & 255 & 31 & 84 & $\begin{array}{c}11.4 \\
30\end{array}$ & 4.2 & 10.8 & $\begin{array}{l}78 \\
49\end{array}$ & 9 \\
\hline $\begin{array}{l}\text { Pterididphytes } \\
\text { Pteridophytes }\end{array}$ & $\begin{array}{l}\text { s. Dennntaaaedticeae } \\
\text { s Denstaaedtiaceae }\end{array}$ & 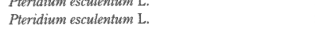 & $\begin{array}{l}\text { fern } \\
\text { fen }\end{array}$ & 12.5 & 0.5 & 14.6 & 2.2 & 1.5 & $\begin{array}{l}458 \\
502\end{array}$ & ${ }_{24}^{24}$ & $\begin{array}{l}6 \\
8 \\
8\end{array}$ & $\begin{array}{l}3.0 \\
2.2\end{array}$ & 0.6 & 12.5 & $\begin{array}{l}49 \\
52\end{array}$ & $\begin{array}{r}7 \\
13\end{array}$ \\
\hline $\begin{array}{l}\text { Pencopopyles } \\
\text { Peridophytes }\end{array}$ & s Dennstaaedtiaceae & Pteridium esculentum L. & fern & 12.5 & 0.5 & 11.8 & 1.8 & $\begin{array}{l}1.6 \\
1.3\end{array}$ & $\begin{array}{l}502 \\
428\end{array}$ & $\begin{array}{l}27 \\
24\end{array}$ & $\begin{array}{r}8 \\
25\end{array}$ & 5.1 & 2.1 & 11.6 & 127 & $\begin{aligned}{ }^{13} \\
8\end{aligned}$ \\
\hline Pteridophytes & Dennstaaedtiaceae & Pteridium esculentum $\mathrm{L}$. & fern & $\begin{array}{l}13.1 \\
133\end{array}$ & $\begin{array}{l}0.5 \\
0.2\end{array}$ & 11.5 & $\begin{array}{l}1.9 \\
5.1\end{array}$ & $\begin{array}{l}1.3 .6 \\
4.6\end{array}$ & 294 & 69 & 112 & 3.4 & 2.0 & 8.4 & 69 & 66 \\
\hline Pteridophytes & Dennstaaedtiaceae & Pteridium esculentum $\mathrm{L}$. & fern & 13. & 0.7 & 14.2 & 2.6 & 2.5 & 396 & 30 & 43 & 4.0 & 5.2 & 10.2 & 20 & 4 \\
\hline Pteridophytes & Dennstaaedtiaceae & 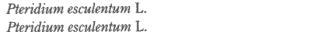 & $\begin{array}{l}\text { ferm } \\
\text { fern }\end{array}$ & 13. & 0.6 & 12.1 & 2.3 & $\begin{array}{l}1.3 \\
3.4\end{array}$ & $\begin{array}{l}407 \\
135\end{array}$ & $\begin{array}{r}17 \\
236\end{array}$ & ${ }_{71}^{2}$ & $\begin{array}{r}4.7 \\
18.2\end{array}$ & $\begin{array}{l}0.3 \\
3.2\end{array}$ & $\begin{array}{l}10.6 \\
11.3\end{array}$ & $\begin{array}{l}88 \\
24\end{array}$ & 17 \\
\hline \multirow[t]{2}{*}{ Pteridophytes 1} & Dennstaaedtiaceae & Pteridium esculentum $\mathrm{L}$. & & 20.0 & 2.5 & 19.7 & 2.6 & $\frac{3.4}{\text { imary } \mathrm{P}}$ & ${ }_{\text {swamp }}^{135}$ & & & & & & 24 & 63 \\
\hline & & & & & & & & imary t & swamp & rest-riv & rine $(\mathrm{Se}$ & a Alam) & & & & \\
\hline $\begin{array}{l}\text { Euatsterid I } \\
\text { Ericales }\end{array}$ & $\begin{array}{l}\text { Apocynaceae } \\
\text { Ebenaceae }\end{array}$ & & tree & 18.7 & 0.5 & 7.9 & 4.8 & 1.8 & $\begin{array}{r}542 \\
1092\end{array}$ & ${ }_{13}^{27}$ & $\begin{array}{r}333 \\
71\end{array}$ & $\begin{array}{l}3.5 \\
1.0\end{array}$ & $\begin{array}{l}1.5 \\
0.8\end{array}$ & $\begin{array}{l}13.3 \\
13.0\end{array}$ & ${ }_{23}^{13}$ & $\begin{array}{r}6 \\
18 \\
\end{array}$ \\
\hline Ericales & & $\begin{array}{l}\text { Diospyros hermaphroditica (Zoll.) Bakh. } \\
\text { Palaquium cochlerifolium P. van Royen }\end{array}$ & $\begin{array}{l}\text { tree } \\
\text { tree }\end{array}$ & $\begin{array}{r}9.2 \\
10.1\end{array}$ & $\begin{array}{l}1.1 \\
0.3\end{array}$ & $\begin{array}{l}5.7 \\
3.9\end{array}$ & $\begin{array}{l}2.9 \\
6.0\end{array}$ & $\begin{array}{l}1.4 \\
2.2\end{array}$ & $\begin{array}{l}10922 \\
1027\end{array}$ & $\begin{array}{l}13 \\
29\end{array}$ & ${ }_{30}^{71}$ & $\begin{array}{l}1.0 \\
1.1\end{array}$ & 0.2 & 11.7 & 52 & $\begin{array}{r}18 \\
4\end{array}$ \\
\hline Ericales & Sapotaceae & $\begin{array}{l}\text { Palaquuium cochherfitolum P. van Royen } \\
\text { Palaquium ridleyi King \& Gamble }\end{array}$ & $\begin{array}{l}\text { tree } \\
\text { tree }\end{array}$ & 10.3 & 0.6 & $\begin{array}{l}.59 \\
3.7\end{array}$ & 8.9 & 5.8 & 1246 & 23 & 1316 & 2.6 & 1.5 & 12.6 & 27 & $\begin{array}{l}4 \\
1\end{array}$ \\
\hline Ericales & Tetrameristaceae & 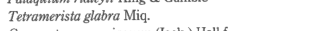 & tree & 9.5 & 0.3 & 13.9 & 2.6 & 0.9 & 699 & 23 & 25 & 1.4 & 3.6 & 12.7 & 10 & 4 \\
\hline Eurosid II & Anacardiaceae & Camnosperma coriaceum (Jack.) Hall.f. & tree & 12.1 & 1.4 & 5.7 & 9.6 & 1.7 & 3753 & 23 & 127 & 0.4 & 1.7 & 13.7 & & 6 \\
\hline rosid II & Anacardiaceae & $\begin{array}{l}\text { Mangifera quadrifida Jack } \\
\text { Durio beccariansu L. }\end{array}$ & tree & 9.5 & 0.2 & 14.3 & 4.4 & 4.4 & 952 & 35 & 43 & 0.6 & 1.3 & 11.5 & 35 & 5 \\
\hline $\begin{array}{l}\text { rosidd II } \\
\text { rosid II }\end{array}$ & $\begin{array}{l}\text { Bombeceae } \\
\text { Diptercarpaceae }\end{array}$ & & tree & 12.4 & 0.5 & 4.0 & 5.8 & 3.3 & 545 & 26 & 47 & 1.1 & 2.7 & 13.2 & $\begin{array}{l}35 \\
{ }_{20}\end{array}$ & 42 \\
\hline $\begin{array}{l}\text { Eurosid II } \\
\text { Eurosid II }\end{array}$ & $\begin{array}{l}\text { Dipterecorarpaceae } \\
\text { Dipterocarpaceae }\end{array}$ & $\begin{array}{l}\text { Shorea teysmanniana Dyer ex Brandis } \\
\text { Shorea teysmanniana Dyer ex Brandis }\end{array}$ & tree & 14.0 & 1.4 & 8.2 & 4.2 & 1.3 & 2322 & $\begin{array}{l}26 \\
39\end{array}$ & $\begin{array}{l}209 \\
247\end{array}$ & $\begin{array}{l}0.3 \\
1.0\end{array}$ & $\begin{array}{r}0.7 \\
11.2\end{array}$ & $\begin{array}{l}12.8 \\
12.3\end{array}$ & 27 & 4 \\
\hline $\begin{array}{l}\text { Eurososid II } \\
\text { Eurs }\end{array}$ & Dipterocarpaceae & $\begin{array}{l}\text { Shorea teysmanniana Dyer ex Brandis } \\
\text { Shorea uliginosa Foxw. }\end{array}$ & tree & 15.1 & 0.6 & 9.2 & 4.9 & 0.8 & 3328 & $\begin{array}{l}39 \\
35\end{array}$ & $\begin{array}{l}247 \\
184\end{array}$ & $\begin{array}{l}1.0 \\
1.3\end{array}$ & $\begin{aligned} 11.2 \\
5.1\end{aligned}$ & $\begin{array}{l}11.3 \\
14.6\end{array}$ & $\frac{1}{10}$ & $\begin{array}{r}18 \\
2\end{array}$ \\
\hline Eurosid II & Melastomataceae & $\begin{array}{l}\text { Shorea uliginosa Foxw. } \\
\text { Dactylocladus stenostachys Oliv., in Hook }\end{array}$ & $\begin{array}{l}\text { tree } \\
\text { tree }\end{array}$ & 12.8 & 0.4 & 3.2 & $\begin{array}{l}4.1 \\
5.9\end{array}$ & $\begin{array}{l}1.2 \\
2.1\end{array}$ & 247 & 38 & 1414 & 0.9 & 3.9 & 11.7 & 8 & 120 \\
\hline Eurosid II & Myrtaceae & Syazygium borneense (Miq.) Muell. Arg. & $\begin{array}{l}\text { tree } \\
\text { tree }\end{array}$ & 10.0 & 0.7 & 3.5 & 6.2 & 2.3 & 1546 & 21 & 29 & 0.8 & 1.2 & 12.7 & 14 & 10 \\
\hline Eurosid II & Myrtaceae & $\begin{array}{l}\text { Syzygium rugosum Korth. } \\
\text { Sylo }\end{array}$ & tree & 6.5 & 0.5 & 8.5 & 3.5 & 2.2 & 863 & 14 & 26 & 0.5 & 0.7 & 12.1 & 6 & 4 \\
\hline rosid II & Myrtaceae & Syzygium sp. & tree & 13.3 & 0.4 & 13.0 & 6.7 & 2.5 & 1007 & 25 & 703 & 1.1 & 1.5 & 12.7 & 53 & \\
\hline rosid II & Myrtaceae & sobovata (Benn.) P. G. Wilson \& Waterh. & tree & 8.1 & 0.2 & 6.0 & 14.1 & 2.1 & 357 & 24 & 80 & 1.7 & 2.5 & 15.0 & $\begin{array}{l}18 \\
36\end{array}$ & 4 \\
\hline osi & Sapindaceae & 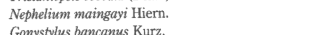 & tree & 16.1 & 0.6 & 9.7 & 3.7 & 1.5 & 770 & 36 & 474 & 3.5 & 3.00 & $\begin{array}{l}11.9 \\
132\end{array}$ & $\begin{array}{l}36 \\
24\end{array}$ & 69 \\
\hline rosid II & Thymelaeaceae & $\begin{array}{l}\text { Gonystylus bancanus Kurz. } \\
\text { Gensy }\end{array}$ & tree & 6.9 & 0.1 & 2.5 & 2.8 & 0.5 & 2407 & ${ }_{32}^{11}$ & 186 & $\begin{array}{l}1.7 \\
1.0\end{array}$ & $\begin{array}{l}0.0 \\
0.8\end{array}$ & 3.2 & ${ }_{23}^{24}$ & $\begin{array}{r}4 \\
57\end{array}$ \\
\hline rosid II & $\begin{array}{l}\text { Thymelaeaceae } \\
\text { Anisphyleaceae }\end{array}$ & & tree & 8.4 & 2 & 2.5 & 3.1 & 0.6 & 1248 & ${ }_{27}^{32}$ & $\begin{array}{l}227 \\
303\end{array}$ & $\begin{array}{l}1.0 \\
4.9\end{array}$ & $\begin{array}{l}0.8 \\
3.5\end{array}$ & $\begin{array}{l}13.0 \\
13.5\end{array}$ & 2090 & $\begin{array}{l}57 \\
38\end{array}$ \\
\hline $\begin{array}{l}\text { rosid I } \\
\text { rosid I }\end{array}$ & $\begin{array}{l}\text { Anisophylleacaeae } \\
\text { Anisophylleaceae }\end{array}$ & $\begin{array}{l}\text { Combretocarpus rotundatus (Miq.) Danser } \\
\text { Combretocarpus rotundatus (Miq.) Danser }\end{array}$ & tree & 11.1 & 1.2 & 6.8 & $\begin{array}{l}4.5 \\
46\end{array}$ & $\begin{array}{l}1.5 \\
1.6\end{array}$ & $\begin{array}{l}981 \\
557\end{array}$ & $\begin{array}{l}27 \\
25\end{array}$ & $\begin{array}{l}303 \\
337\end{array}$ & $\begin{array}{l}4.9 \\
4.2\end{array}$ & $\begin{array}{l}3.5 \\
1.7\end{array}$ & $\begin{array}{l}13.5 \\
13.3\end{array}$ & 2005 & $\begin{array}{r}38 \\
7\end{array}$ \\
\hline $\begin{array}{l}\text { rosid I } \\
\text { rosid I }\end{array}$ & $\begin{array}{l}\text { Ansoponylilaceacee } \\
\text { Caesalpiniaceae }\end{array}$ & & tree & 10.6 & $\begin{array}{l}0.8 \\
0.4\end{array}$ & $\begin{array}{l}7.1 \\
2.7\end{array}$ & $\begin{array}{l}4.6 \\
6.4\end{array}$ & $\begin{array}{l}1.6 \\
3.0\end{array}$ & $\begin{array}{l}57 \\
303\end{array}$ & $\begin{array}{l}23 \\
23\end{array}$ & 216 & 8.5 & 0.3 & 12.8 & 26 & 139 \\
\hline rosid I & Chrysobalanaceae & $\begin{array}{l}\text { Koompassia malaccensis } \\
\text { Parastemon urophylus }\end{array}$ & $\begin{array}{c}\text { tree } \\
\text { trae }\end{array}$ & $\begin{array}{l}11.5 \\
10.1\end{array}$ & 0.4 & $\begin{array}{l}2.7 \\
6.7\end{array}$ & $\begin{array}{l}6.4 \\
7.3\end{array}$ & 2.8 & 124 & 50 & 352 & 71.9 & 3.1 & 14.5 & 26 & $\begin{array}{r}159 \\
5\end{array}$ \\
\hline rosid I & Clusiace & $\begin{array}{l}\text { urophyllus }(t) \\
\text { minophylum }\end{array}$ & $\begin{array}{l}\text { tree } \\
\text { tree }\end{array}$ & $\begin{array}{l}10.1 \\
8.0\end{array}$ & 0.2 & $\begin{array}{l}8.1 \\
3.0\end{array}$ & 3.6 & 0.8 & 1056 & 18 & 32 & 1.1 & 0.6 & & 53 & 33 \\
\hline rosid I & Clusiaceae & hyllum 1 & tree & 11.2 & 0.3 & 10.0 & 7.4 & 4.5 & 80 & 48 & 366 & 5.3 & 3.5 & 12 & 86 & 8 \\
\hline rosi & Euph & (iq.). Muell. Arg. & tree & 13.8 & 0.5 & 6.6 & 7.8 & 2.8 & 889 & 31 & 76 & 0.7 & 1.6 & & 28 & 115 \\
\hline rosid I & Hyperic & 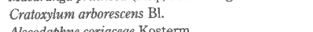 & tree & 10.9 & 0.4 & 5.1 & 4.8 & 1.2 & 981 & 33 & $\begin{array}{l}311 \\
39\end{array}$ & 2.8 & 62 & 13. & 79 & 20 \\
\hline $\begin{array}{l}\text { Laurales } \\
\text { Laurales }\end{array}$ & $\begin{array}{l}\text { Lauraceae } \\
\text { Lauraceae }\end{array}$ & $\begin{array}{l}\text { Alseodaphne coriaceae Kosterm. } \\
\text { Dehaasia caesia Blume }\end{array}$ & tree & 6.2 & 3 & 8.4 & $\begin{array}{l}5.2 \\
5.9\end{array}$ & 3.3 & 974 & ${ }_{74}^{23}$ & $\begin{array}{l}39 \\
62\end{array}$ & $\begin{array}{l}1.0 \\
1.0\end{array}$ & $\begin{array}{l}0.8 \\
0.5\end{array}$ & 13.4 & 18 & $\begin{array}{r}5 \\
99\end{array}$ \\
\hline & & Dehaasia caesia Blume & tree & 12.3 & 0.4 & 4.9 & & nary pe & vamp fff & est-den & e pole (s & tia Alam) & & & & \\
\hline Euasterid II & Aquifoliaceae & & & & & & 9.8 & 4.3 & 1 & 31 & 1128 & 0.6 & 4.9 & .7 & & \\
\hline . & Apocynaceae & rymosa Bl. & $\begin{array}{l}\text { tree } \\
\text { tree }\end{array}$ & $\begin{array}{l}13.9 \\
16.0\end{array}$ & 0.4 & $\begin{array}{l}14.8 \\
8.4\end{array}$ & 7.8 & 1.4 & & 35 & 435 & 0.4 & 0.9 & & 12 & \\
\hline lasterid I & Rubiace & nonius flavescens (Jack) Backer & tree & 8.5 & 0.2 & 5.1 & 15.5 & 1.5 & 39 & 21 & 95 & 1.1 & 0.8 & 14.8 & 12 & 17 \\
\hline cale & Ebenaceae & (Zoll.) Bakh. & tree & 9.8 & 0.5 & 3.8 & 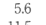 & 3 & & 36 & $\begin{array}{r}99 \\
522\end{array}$ & 0.3 & $\begin{array}{l}2.0 \\
3.9\end{array}$ & $\begin{array}{r}9.7 \\
11.2\end{array}$ & $\begin{array}{r}6 \\
30\end{array}$ & 58 \\
\hline $\begin{array}{l}\text { Ericales } \\
\text { Ericales }\end{array}$ & $\begin{array}{l}\text { Sapotaceae } \\
\text { Sampatceae }\end{array}$ & V.r.) Piere ex Dubard & tre & 11.1 & o & 6.9 & $\begin{array}{l}11.5 \\
1.96\end{array}$ & 51 & 5 & $\begin{array}{l}46 \\
37\end{array}$ & $\begin{array}{r}522 \\
44\end{array}$ & $\begin{array}{l}0.4 \\
4.5\end{array}$ & $\begin{array}{l}3.9 \\
4.5\end{array}$ & $\begin{array}{r}11.2 \\
9.6\end{array}$ & $\begin{array}{l}30 \\
38\end{array}$ & ${ }_{4}^{5}$ \\
\hline $\begin{array}{l}\text { Ericales } \\
\text { Ericales }\end{array}$ & $\begin{array}{l}\text { Sapotaceae } \\
\text { Tetrameristaceae }\end{array}$ & $\begin{array}{l}\text { aquium rideyii King \& Gamble } \\
\text { qumerista glabra Miq. }\end{array}$ & tr & 8.5 & 0.4 & 9.2 & $\begin{array}{c}19.6 \\
4.8\end{array}$ & ${ }_{1.1}^{5.1}$ & 75 & $\begin{array}{l}37 \\
15\end{array}$ & ${ }_{38}^{44}$ & $\begin{array}{l}4.5 \\
0.4\end{array}$ & $\begin{array}{l}4.0 \\
3.0\end{array}$ & 10.8 & $\begin{array}{l}58 \\
17\end{array}$ & 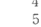 \\
\hline $\begin{array}{l}\text { Irosid II } \\
\text { II }\end{array}$ & $\begin{array}{l}\text { Tetrameristaceae } \\
\text { Anacardiaceae }\end{array}$ & $\begin{array}{l}\text { Tetramerista glabra } \mathrm{M} \\
\text { Camnosperma coriacen }\end{array}$ & & & $\begin{array}{l}0.3 \\
0.5\end{array}$ & $\begin{array}{l}9.6 \\
73\end{array}$ & $\begin{array}{c}4.8 \\
17.3\end{array}$ & ${ }_{2.8}^{1.1}$ & 23 & 43 & 132 & 1.5 & 3.3 & 15 & 79 & 15 \\
\hline rosi & Caesalpiniar & ${ }_{K}^{C}$ & ${ }_{\text {tr }}^{\operatorname{tr}}$ & 10 & 0.3 & 5.3 & 8.5 & 25 & 40 & 27 & 164 & 2.9 & 1.4 & & 22 & 36 \\
\hline ros & Dipt & & tr & 10 & 0.3 & 8.0 & 5.4 & 1.3 & 30 & 35 & 52 & 0.9 & 2.9 & 15 & 19 & . \\
\hline Lu & ataceae & look & & 80 & 0.3 & 9.1 & 10.0 & 2.1 & & 15 & 31 & 1.0 & 3.0 & .9 & 26 & 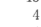 \\
\hline$F$ & Mytac & Muell. Agr. & & 9.2 & 0.2 & 7.0 & 28.7 & 2 & 5 & 23 & 27 & 0.1 & 1.1. & & 280 & 4 \\
\hline Eurosid II & Myrtaceae & rugosum Ko & & 7.4 & & 6.0 & 13.6 & 3.9 & te & 16 & $\begin{array}{l}30 \\
20\end{array}$ & 1.1 & 1.0 & 13.0 & 30 & 15 \\
\hline $\begin{array}{l}\text { Eurosid II } \\
\text { Eurosid II }\end{array}$ & $\begin{array}{l}\text { Myrtaceae } \\
\text { Sonindroeee }\end{array}$ & $s$ & & & 3 & 6.1 & 5.5 & 4.2 & 5 & $\begin{array}{l}22 \\
35\end{array}$ & $\begin{array}{l}29 \\
24\end{array}$ & 0.9 & 2.6 & 4 & 30 & 2 \\
\hline Eurosid II & Sapindace & & & 10. & 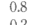 & 6.0 & 6.5 & 13 & $\begin{array}{l}555 \\
709\end{array}$ & $\begin{array}{l}35 \\
18\end{array}$ & $\begin{array}{r}24 \\
330\end{array}$ & 0.4 & 4.3 &.$^{2}$ & 10 & \\
\hline & & & & 9 & 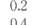 & 4.8 & 5.2 & 1.3 & $\begin{array}{r}709 \\
28\end{array}$ & $\begin{array}{l}18 \\
32\end{array}$ & ${ }_{18}^{33}$ & 0 & 2.7 & $\begin{array}{l}11.0 \\
13.5\end{array}$ & $\begin{array}{r}19 \\
699\end{array}$ & \\
\hline & $\mathrm{Ani}$ & (Miq.) Danser & & 12 & 0.4 & 3.9 & $\begin{array}{l}5.6 \\
3.1\end{array}$ & 0 & ${ }_{401}^{28}$ & $\begin{array}{l}32 \\
29\end{array}$ & $\begin{array}{c}18 \\
28 \\
28\end{array}$ & 1.72 & 2.1 & $\begin{array}{l}13.5 \\
159\end{array}$ & 6911 & \\
\hline & & . & tr & 10 & 0.2 & $\begin{array}{l}5.1 \\
4.3\end{array}$ & $\begin{array}{l}3.1 \\
4.5\end{array}$ & 1. & $\begin{aligned} 401 \\
58\end{aligned}$ & $\begin{array}{l}29 \\
21\end{array}$ & ${ }_{132}^{28}$ & $\begin{array}{l}1.0 \\
03\end{array}$ & $\begin{array}{l}3.3 \\
20\end{array}$ & $\begin{array}{l}15.9 \\
131\end{array}$ & $\begin{array}{l}17 \\
10\end{array}$ & 1 \\
\hline & $\mathrm{Clu}$ & annii Miq. & tr & 10 & 0.2 & $\begin{array}{l}4.3 \\
8.9\end{array}$ & $\begin{array}{r}4.5 \\
24.3\end{array}$ & 6. & $\begin{array}{l}50 \\
566\end{array}$ & $\begin{array}{l}21 \\
38\end{array}$ & 70 & 150 & 2.0 & $\begin{array}{r}13.1 \\
9.4\end{array}$ & $\begin{array}{l}10 \\
27\end{array}$ & \\
\hline & Clusiac & cinia & trits & 10 & $\begin{array}{l}0.4 \\
03\end{array}$ & 8.9 & $\begin{array}{r}24.3 \\
5.4\end{array}$ & & 247 & 23 & 223 & $\begin{array}{l}15.0 \\
13\end{array}$ & $\begin{array}{l}2.9 \\
4.8\end{array}$ & $\begin{array}{r}9.4 \\
15.7\end{array}$ & $\begin{array}{r}27 \\
8\end{array}$ & \\
\hline - & Hypericaceae & scens BI. & & 11 & 0.5 & 3.28 & 3.4 & $\begin{array}{l}1.1 \\
2.0\end{array}$ & 111 & 38 & 223 & 0.4 & $\begin{array}{l}4.8 \\
1.7\end{array}$ & $\begin{array}{l}15.7 \\
11.2\end{array}$ & $\begin{array}{l}8 \\
14\end{array}$ & . \\
\hline Eurosid I & Moraceae & $c a p a$ L $\mathrm{L}$. & to & 12.9 & 0.5 & $\begin{array}{r}5.0 \\
10.6\end{array}$ & 12.8 & 6.6 & 533 & 41 & & 0.4 & $\begin{array}{l}1.1 \\
2.9\end{array}$ & $\begin{array}{l}1.2 \\
10.3\end{array}$ & 16 & \\
\hline Magnoliales & $\begin{array}{l}\text { Annonaceae } \\
\text { Myristicaceaee }\end{array}$ & $\begin{array}{l}\text { atusca Maning. } \\
\text { ildia subglobosa }\end{array}$ & & 6.8 & 0.4 & 2.4 & 17.5 & 11.2 & 433 & 42 & 1064 & 6.5 & $\begin{array}{l}2.9 \\
2.0\end{array}$ & .1 .5 & 2 & 7 \\
\hline $\begin{array}{l}\text { Magnoliales } \\
\text { Layrules }\end{array}$ & $\begin{array}{l}\text { Myristicaceae } \\
\text { Lauraceae }\end{array}$ & $\begin{array}{l}\text { etdala subghobo } \\
\text { daphne coriace }\end{array}$ & tr & 8.5 & 0.2 & & 13.6 & 2. & 799 & 17 & 38 & 0.5 & 1.6 & 10.3 & 32 & 13 \\
\hline $\begin{array}{l}\text { Latrales } \\
\text { Laurales }\end{array}$ & $\begin{array}{l}\text { Laarucaeae } \\
\text { Lauraceae }\end{array}$ & $\begin{array}{l}\text { aphomum con sintoc Bl. } \\
\text { al. }\end{array}$ & tr & 9.2 & 0.4 & 6.2 & 8.0 & 2.3 & 558 & 28 & 400 & 0.4 & 2 & 11.3 & 26 & 68 \\
\hline $\begin{array}{l}\text { Laurlates } \\
\text { Laurales }\end{array}$ & $\begin{array}{l}\text { Lauracaeae } \\
\text { Lauraceae }\end{array}$ & 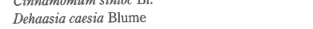 & tree & 12.6 & 0.4 & 8.4 & 9.2 & 3.5 & 852 & 34 & 78 & 0.4 & 0.5 & 8.3 & 18 & 18 \\
\hline
\end{tabular}

* Classification used following the Angiosperm Phylogeny Group (APG, 1998) and Soltis et al. (1999), and Pteridophytes group was also added. 